\title{
Cancer Metastases to Bone: Concepts, Mechanisms, and Interactions with Bone Osteoblasts
}

\author{
Alison B. Shupp ${ }^{\dagger}$, Alexus D. Kolb ${ }^{\dagger}$, Dimpi Mukhopadhyay and Karen M. Bussard * (D) \\ Department of Cancer Biology, Thomas Jefferson University, Philadelphia, PA 19107, USA; \\ Alison.Shupp@jefferson.edu (A.B.S.); Alexus.Kolb@jefferson.edu (A.D.K.); \\ Dimpi.Mukhopadhyay@jefferson.edu (D.M.) \\ * Correspondence: karen.bussard@jefferson.edu \\ t These authors contributed equally to this work.
}

Received: 4 April 2018; Accepted: 31 May 2018; Published: 4 June 2018

\begin{abstract}
The skeleton is a unique structure capable of providing support for the body. Bone resorption and deposition are controlled in a tightly regulated balance between osteoblasts and osteoclasts with no net bone gain or loss. However, under conditions of disease, the balance between bone resorption and deposition is upset. Osteoblasts play an important role in bone homeostasis by depositing new bone osteoid into resorption pits. It is becoming increasingly evident that osteoblasts additionally play key roles in cancer cell dissemination to bone and subsequent metastasis. Our laboratory has evidence that when osteoblasts come into contact with disseminated breast cancer cells, the osteoblasts produce factors that initially reduce breast cancer cell proliferation, yet promote cancer cell survival in bone. Other laboratories have demonstrated that osteoblasts both directly and indirectly contribute to dormant cancer cell reactivation in bone. Moreover, we have demonstrated that osteoblasts undergo an inflammatory stress response in late stages of breast cancer, and produce inflammatory cytokines that are maintenance and survival factors for breast cancer cells and osteoclasts. Advances in understanding interactions between osteoblasts, osteoclasts, and bone metastatic cancer cells will aid in controlling and ultimately preventing cancer cell metastasis to bone.
\end{abstract}

Keywords: osteoblast; osteoclast; metastasis; breast cancer; prostate cancer; multiple myeloma; bone; dormancy; re-activation; osteomimicry

\section{Introduction}

Bone is a unique organ of the body capable of providing structural support, regulation of calcium levels in blood, as well as protection of internal soft tissue organs [1]. To accomplish these functions, bone undergoes a dynamic process of remodeling to respond to mechanical strain and stress. Importantly, bone is predominantly composed of type I collagen, followed by other non-collagenous proteins and proteoglycans which harden through a process called mineralization [1]. Mineralization increases bone strength and resistance to compression [2].

There are two types of bone found within the body: cortical bone and trabecular bone [1]. Cortical bone is a dense layer of outer tissue that plays a vital role in supporting the weight load of the body, as well as provides protective functions. Cortical bone is composed of densely packed collagen fibrils that are aligned along the longitudinal axis of bone, and parallel to hydroxyapatite crystals in a manner that permits bone to resist tensile strain [3,4]. On the other hand, trabecular bone consists of a large, porous matrix located on the inner surface of bone ends. Long bones, including the humerus and femur, as well as flat and irregular bones, such as vertebrae and the sternum, are predominantly composed of trabecular bone [5]. While both cortical and trabecular bone are metabolically active, trabecular bone undergoes remodeling at a rate higher than cortical bone [1]. 


\subsection{Gross Anatomy of Bone}

Bone is a complex tissue and has many unique properties that make it a hospitable microenvironment for metastatic cancer cells. Both breast and prostate cancer are known for their inclination to metastasize to bone [6-8]. The skeleton is comprised of four types of bones: short bones, long bones, flat bones and irregular bones [9]. Short bones are similar in shape to a cube, and can be found in the wrist or ankle. Flat bones are flattened plates of bone that are often curved in shape, such as the skull and mandible, while irregular bones have a non-uniform shape (e.g., vertebrae and sacrum). Lastly, long bones, such as the femur and humerus, support the limbs of the body. These types of bones differ in both their function and structural organization. All bones contain a dense outer layer of bone, called cortical bone, but they differ in their relative amounts of cortical bone and trabecular bone. Cortical bone, also called compact bone, is formed from densely packed collagen fibrils, in particular type I collagen [1,10]. Located in the interior of bone and near bone ends, is trabecular bone, also referred to as cancellous bone or spongy bone. This type of bone is less dense than cortical bone, and consists of a porous matrix. While cortical bone imparts strength and structure to the skeleton that is necessary to support the body, trabecular bone provides flexibility needed for withstanding mechanical force [11].

Long bones consist of three regions: the epiphysis, metaphysis, and diaphysis (Figure 1). The epiphysis is located at the ends of long bones, above the growth plate, where bone growth and elongation occurs. The diaphysis is the shaft of long bones, which consists of cortical bone that surrounds a bone marrow-filled cavity [12]. The metaphysis is adjacent to the epiphysis, but below the growth plate, and is composed of trabecular bone. The metaphysis has sinusoidal vasculature that results in slow-moving blood flow through blood vessels compared to capillary networks. This sluggish blood flow in vascular sinusoids is ideal for movement of hematopoietic and lymphoid cells in and out of the bone, but it is also exploited by cancer cells trafficking to bone $[6,13]$.

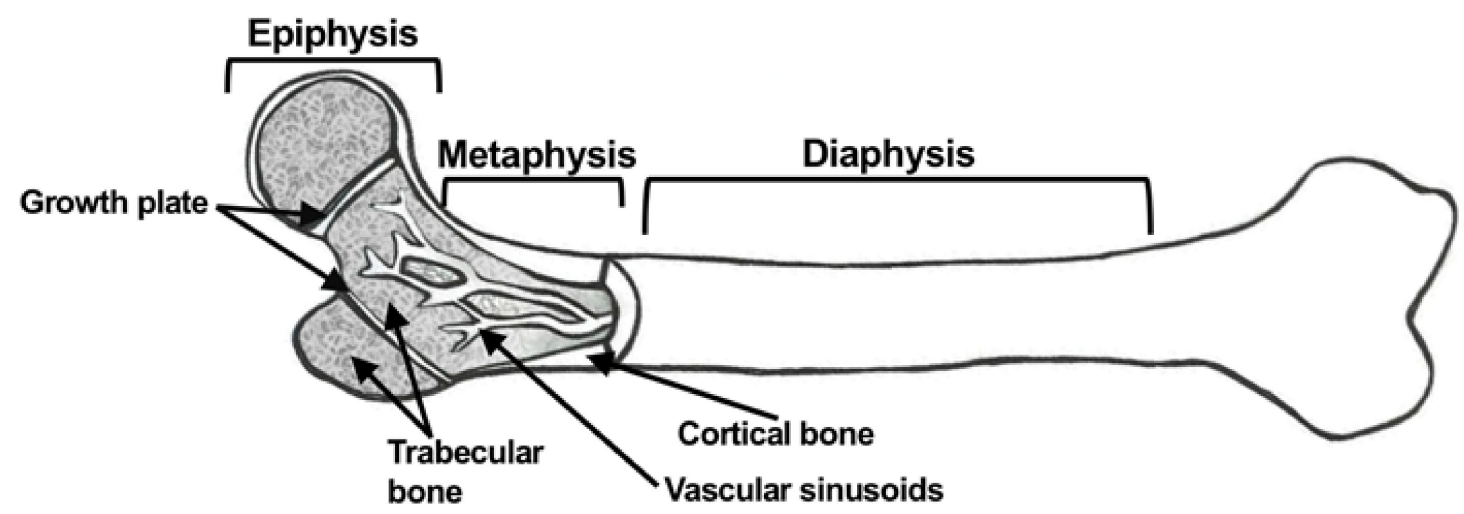

Figure 1. Anatomy of long bones. Depicted are the three regions of long bones: epiphysis, metaphysis, and diaphysis. The outside of the bone is composed of dense cortical bone, while trabecular bone can be found in the interior and near bone ends. Also indicated are the growth plates, at the ends of the bone, and the sinusoidal vasculature that is found in the epiphysis.

\subsection{Bone Physiology, Remodeling, and Metabolism}

Bone is an extremely metabolically active tissue that is constantly being remodeled. There are three main cell types that facilitate bone remodeling: osteoblasts, osteoclasts, and osteocytes. Osteoblasts account for $4-6 \%$ of the total cells in bone [14]. Osteoblasts synthesize and mineralize new bone matrix, called osteoid, while osteoclasts degrade existing bone. Bone matrix is largely composed of type I collagen, but also contains proteoglycans and other extracellular matrix proteins [10]. Osteoblasts, derived from mesenchymal stem cells, aid in matrix mineralization through the formation of hydroxyapatite crystals. As osteoid is synthesized, some osteoblasts become embedded into the 
bone matrix and develop into osteocytes. Osteocytes form interconnected networks through small tunnels called canaliculi. Osteocytes, which account for $90-95 \%$ of all cells in the bone, are important for detection of mechanical forces, and communicating to osteoblasts and osteoclasts to induce bone deposition or bone resorption as a response [15].

Osteoclasts, the cells responsible for resorbing existing bone, are derived from monocytes present in bone marrow. Osteoclasts account for $1-4 \%$ of the total cells in bone $[14,16]$. Mature osteoclasts are formed via RANK-L (receptor activator for nuclear factor kappa beta (NF- $\mathrm{B}$ ) ligand) signaling. RANK-L, which is abundantly produced by osteoblasts, binds the RANK receptor on monocytes [17]. Another stimulus that induces mature osteoclast formation is the presence of macrophage colony stimulating factor (M-CSF). In the presence of M-CSF and RANK-L, multiple monocytes fuse together to form a mature and multinucleated osteoclast [17]. Osteoclasts have a unique morphology that optimizes them for bone resorption. Their cell membrane forms a ruffled border with the surface of the bone matrix. The ruffled structure increases membrane surface area through which bone-degrading enzymes, such as tartrate resistant acid phosphatase (TRAP) can be secreted [18]. As osteoclasts resorb bone, various growth factors (e.g., bone morphogenic proteins (BMPs), tumor-growth factor-beta (TGF-B), insulin growth factor (IGF)), cytokines, and chemokines that are embedded in the bone matrix are released into the microenvironment [19].

\subsection{Osteoblast Differentiation}

Bone contains pre-osteoblast cells that migrate to the site of bone resorption, differentiate into mature osteoblasts, and secrete bone matrix to fill in the resorption cavities [1]. Osteoblasts are derived from precursor mesenchymal stromal cells which can be found in the bone marrow stroma [1]. Upon stimulation by local growth factors and bone morphogenetic proteins, mesenchymal stromal cells proliferate to form pre-osteoblast cells, which then later differentiate into mature osteoblasts [20]. Mature osteoblasts are responsible for laying down new bone, which is composed of both type I collagen and non-collagenous proteins ( $22 \%)$ [1]. The remaining $\sim 80 \%$ composition is made of up water ( $8 \%$ by weight) and hydroxyapatite $(\sim 70 \%)[3]$.

Murine osteoblast differentiation is characterized by three principle periods distinguished by markers indicative of each stage: proliferation ( $\sim 9$ days), extracellular matrix maturation ( 12 days), and extracellular matrix mineralization ( 25 days) [21] (Figure 2).

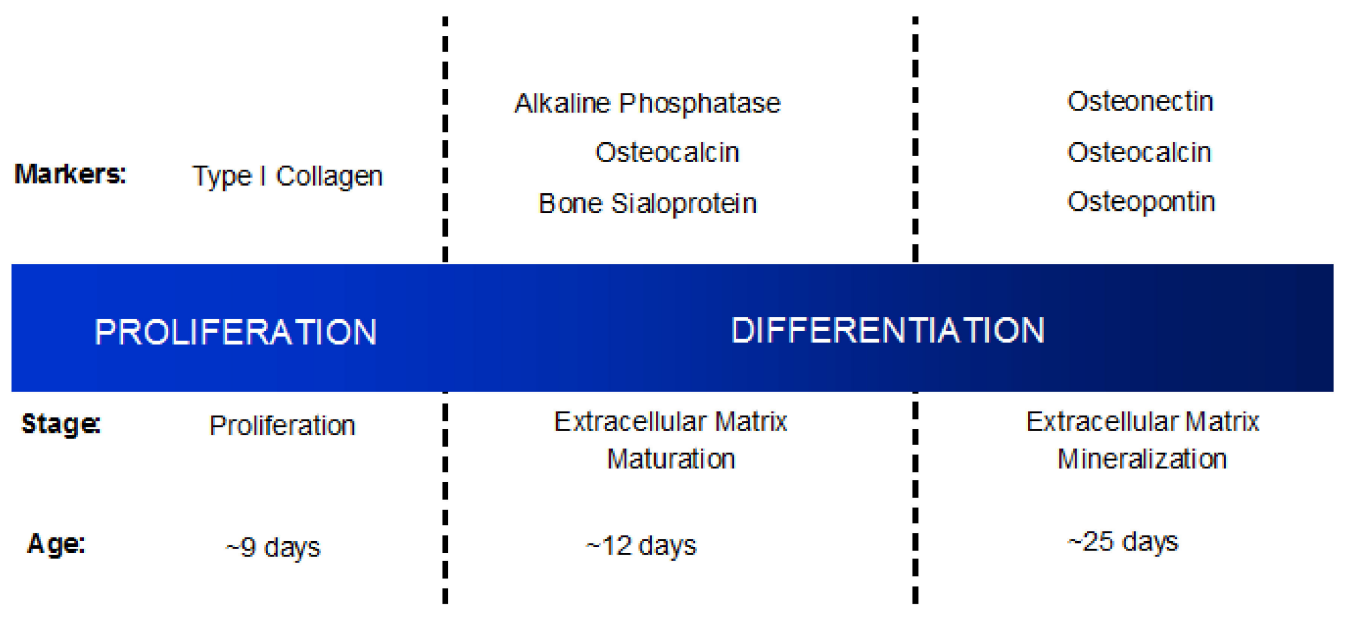

Figure 2. Osteoblast differentiation. Murine osteoblast differentiation is characterized by three stages of growth marked by specific factor expression. During osteoblast proliferation (up to approximately 9 days), osteoblasts produce type I collagen. Osteoblasts enter early differentiation, or extracellular matrix maturation, at approximately 12 days of age, and express the proteins alkaline phosphatase, osteocalcin, and bone sialoprotein. Extracellular matrix mineralization occurs when osteoblasts are approximately 25 days old, where osteoblasts express the proteins osteonectin, osteocalcin, and osteopontin. 
Proliferation is characterized by the secretion of type I collagen, while alkaline phosphatase, bone sialoprotein, and osteocalcin indicate extracellular matrix maturation [21]. The presence of osteopontin, osteocalcin, and osteonectin signal extracellular matrix mineralization, which is also marked by bone nodule formation [21]. Osteoblast differentiation is continuously ongoing, working in concert with osteoclast bone-resorption.

\subsection{Osteoblasts Work in Concert with Osteoclasts to Regulate Bone Remodeling}

Osteoclasts are responsible for bone resorption. These resorptive cells are derived from monocytes located in the bone marrow stroma [17]. In order to activate osteoclasts, osteoblasts express RANK-L on their plasma membrane surface. This ligand binds to the receptor RANK found on the surface of osteoclast progenitor cells [22]. Osteoprotegerin (OPG) is a decoy receptor for RANK-L, and is also produced by osteoblasts. The ratio of osteoblast-derived RANK-L: OPG is one manner in which osteoblasts regulate osteoclastogenesis [22]. When RANK-L expression is high and OPG expression is low, osteoclastogenesis will predominate. When OPG levels are raised, OPG will bind RANK-L, thus suppressing osteoclast activation [22]. In addition to RANK-L and OPG, osteoblasts secrete M-CSF, which binds to the colony-stimulating factor-1 receptor (c-fms) on osteoclasts to further stimulate osteoclastogenesis [23,24]. Mature osteoclasts form from the fusion of several monocytes to form one large, multinucleated osteoclast [17]. Upon the release of signals to stimulate bone resorption, multi-nucleated osteoclasts become activated, and bind to the bone matrix. Bone resorption occurs via osteoclast secretion of metalloproteinases (MMPs), cysteine proteinases (including cathepsin K), phosphatases, lysozymal enzymes, and low pH molecules including citric acid and hydrochloric acid [17,25-27].

Under conditions of normal bone homeostasis, there is a tightly regulated balance between bone deposition and resorption, where there is no net bone gain or loss. However, this balance is upset in several pathological conditions, including osteomyelitis, osteoarthritis, and bone metastatic cancers [28-31]. In each of these conditions, and especially in osteolytic disease, osteoclasts are overstimulated to degrade bone. Osteoblasts do not deposit new bone; thus resulting in net bone loss [32].

\section{Osteoblasts in the Bone Microenvironment as Contributors to Bone Disease and Degradation}

As previously discussed, bone homeostasis is controlled by a tightly regulated balance between bone deposition and bone resorption [6]. However, this balance can be upset in situations of infection [33], chronic inflammation [34,35], or cancer [6]. In particular, osteoblast activity has been shown to be dysregulated in pathological conditions of bone infection such as osteomyelitis. Osteomyelitis is a severe bone infection, typically caused by the bacterium Staphylococcus aureus, which, if left untreated, can lead to patient death [36,37]. In adults, S. aureus infection and subsequent osteomyelitis are typically associated with surgical osseointegration implants (e.g., femoral implants [artificial hip] or dental implants) [38-40]. Interestingly, S. aureus is highly adapted to specifically interact with bone osteoblasts as a result of microbial surface components recognizing adhesive matrix molecules, namely bone sialoprotein, osteopontin, type I collagen, fibronectin, and integrin alpha 5 beta $1[29,41]$. All of these factors are strongly expressed by bone osteoblasts as compared to other cells of the bone niche [6]. Crosstalk between S. aureus and osteoblasts through these mechanisms permits the internalization of $S$. aureus by osteoblasts, as well as allows $S$. aureus to escape immune detection and cause sustained bone infection [42]. Upon internalization of S. aureus, osteoblasts increase their production of inflammatory cytokines including interleukin-6 (IL-6), monocyte chemoattractant protein-1 (MCP-1), regulated on activation normal T cell expressed and secreted (RANTES), and macrophage inflammatory protein-1 alpha (MIP-1 alpha); factors that stimulate osteoclastogenesis including granulocyte-colony stimulating factor (G-CSF), RANK-L, and granulocyte macrophage-colony stimulating factor (GM-CSF); and cytokines that recruit both innate and adaptive immune cells including interleukin-8 (IL-8), interleukin-12 (IL-12), and interferon gamma-induced protein 10 (IP-10) [43-49]. Interestingly, these same cytokines have also been shown 
to be upregulated by osteoblasts during bone invasion by metastatic breast cancer cells [50-52]. In addition, sustained chronic infection of osteoblasts by $S$. aureus has been found to lead to a reduction in osteoblast proliferation; decreased differentiation as evidenced by reduced expression of the bone turnover markers alkaline phosphatase, osteocalcin, osteonectin, and osteopontin; and a reduction in calcium deposition and osteoblast mineralization $[49,53,54]$. Ultimately, osteoblasts die due to the sustained infection [55]. Furthermore, the increase in cytokines produced by osteoblasts as a result of sustained infection are capable of eliciting increased osteoclastogenesis [49]. As a result of increased osteoclast formation, yet decreased osteoblast activity, bone is resorbed at a rate higher than it is deposited, leading to sustained bone degradation and perpetuated bone loss [56]. A detailed review of interactions between osteoblasts and S. aureus can be found in [29].

In addition to osteomyelitis, osteoarthritis is a common joint disease typically characterized by chronic inflammation and altered osteoblast function. It has been demonstrated that osteoblasts produce increased amounts of the inflammatory cytokines IL-6, IL-8, prostaglandin E2 (PGE2), and vascular endothelial growth factor (VEGF); extracellular matrix markers matrix metalloproteinase-9 (MMP-9) and type I collagen; as well as tumor-growth factor beta-1 (TGF-beta 1) in regions of sclerotic bone as compared to normal bone $[30,31,57]$. And, similar to osteomyelitis, regions of osteoarthritis are marked by an imbalance in alkaline phosphatase expression, and a reduction in osteoblast mineralization and bone sialoprotein expression [58,59]. Moreover, there is an imbalance in the ratio of RANK-L/OPG produced by osteoblasts leading to alterations in bone remodeling [60]. Thus, osteoblast function, including production of cytokines, growth factors, and osteoclastogenesis-initiating factors, as well as osteoblast differentiation and mineralization, is altered in chronic states of disease in bone.

\section{Bone Is a Favored Site for Cancer Cell Metastasis}

In 1889, in an attempt to explain directional tropism of disseminated breast cancer cells for certain organs of the body as opposed to others, Stephen Paget made the statement "When a plant goes to seed, its seeds are carried in all directions; but they can only live and grow if they fall on congenial soil [61]." Nearly 130 years later, Paget's "seed and soil" hypothesis best describes the crosstalk between the tumor cell (the "seed") and secondary microenvironments (the "soil"). Bone is an especially congenial soil for cancer cell metastasis mainly due to it being a rich source of growth factors, neovascularization factors, cytokines, and chemokines that facilitate cancer cell colonization, growth, and sustained survival [6]. Furthermore, mounting evidence has implicated the cells of the bone responsible for remodeling, the osteoblasts and osteoclasts, as key players in bone metastatic cancer cell progression, including cancer cell homing to and seeding in bone, dormancy, cancer cell re-activation, and contribution to macrometastatic lesion growth. These topics will be discussed in detail in future sections, but can be broadly defined as events that occur either in early stage disease, disease progression, or late or advanced stage disease (Figure 3). Late or advanced stage bone metastases are typically characterized by macrometastatic lesion formation and extensive tumor cell colonization of bone [62]. Patients presenting with advanced stage disease frequently experience bone pain, hypercalcemia, and fractures [63]. As a result, patient quality of life is impacted. Treatment modalities are mainly palliative to alleviate complications associated with increased skeletal tumor burden [63] (Figure 3). These characteristics are in contrast to early stage cancer-induced bone disease characterized on the basis of the seeding of solitary or single disseminated tumor cells in the bone [64]. As a result of their small size, tumor cells at this stage may be undetectable by currently available technologies. Cancer cell dormancy may also occur [64] (Figure 3). We previously conducted a comprehensive detailed analysis of the kinetics of breast cancer cell trafficking into the bone and changes in the dynamic progression of disease over time with respect to cancer cells, osteoblasts, and osteoclasts, which can be found in [62]. Furthermore, Mastro and colleagues conducted a study that describes alterations in disease progression, especially in late stage bone metastatic breast cancer, with respect to spatial distribution of cancer cells and osteoblasts, which can be found in [28]. 


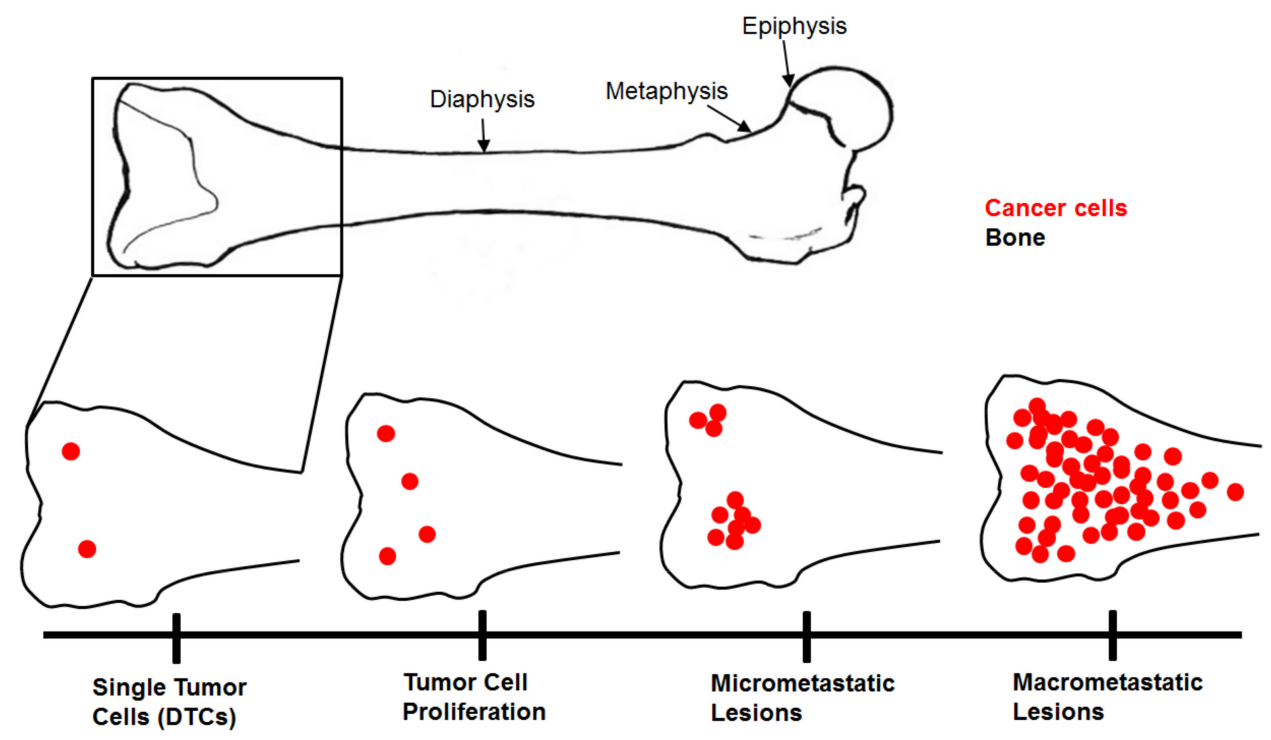

Early Stage Disease:

Disseminated Tumor Cell

Seeding;

Possible Tumor Cell

Dormancy.

Lesion May Be Undetectable.
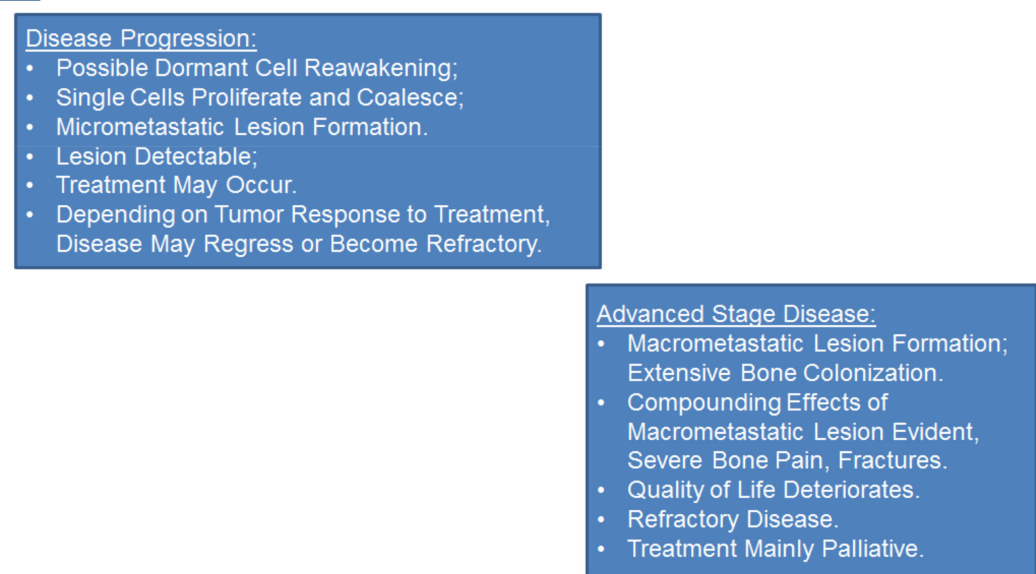

Disease Progression

Figure 3. Stages of disease progression during bone metastatic cancer. Bone metastatic cancers may be broadly defined by three overarching stages: early disease, disease progression, and advanced or late stage disease. During early stage disease, disseminated tumor cells circulating in the vasculature enter bone and seed mainly as single cells. Cells may be undetectable by current technological methods due to their solitary nature. Cancer cell dormancy may also occur. As bone metastatic disease progresses over a period of months to years to potentially decades, dormant cancer cells become re-awakened leading to proliferation and coalescing of smaller, micrometastatic lesions. Lesions may become detectable by current technological methods. Treatments to reduce tumor size and alter bone remodeling may occur. Over time, tumors may become refractory to treatment modalities, leading to sustained tumor cell proliferation and excessive tumor burden. Macrometastatic lesions form. Patients may experience effects of increased tumor burden including severe bone pain, fractures, and hypercalcemia. Patient quality of life progressively deteriorates. Treatment modalities during advanced stage disease are mainly palliative to reduce complications from excessive bone tumor burden. 
Similar studies were carried out focusing on early events in bone metastatic prostate cancer by Wang et al. yielding comparable results with respect to preferential localization of cancer cells to endosteal regions of bone, including preferred trafficking of cancer cells to the endosteal marrow as opposed to central marrow [65].

Cancer cells, including those of prostate [66], breast [67], and multiple myeloma [68] frequently metastasize to bone. Other cancers, including lung [69,70], liver [71], kidney [72], and thyroid [73] also metastasize to bone, but at a less frequent rate than prostate, breast, or multiple myeloma.

\subsection{Breast Cancer Metastases to Bone}

It has been estimated that between $20-30 \%$ of breast cancer patients will develop metastases [74], with bone metastases resulting in approximately $15 \%$ of these patients [75]. Among these, approximately $50 \%$ of metastases will involve bone as a primary metastatic site, whereas $80 \%$ involve bone as a secondary and/or recurring metastatic site [7,76-78]. Once breast cancer metastasizes to the bone, the 5 years relative survival rate falls to under $10 \%$ [76]. At the present time, there is no cure for breast cancer that has metastasized to the bone.

Metastatic lesions that form as part of bone metastatic breast cancer disease are predominantly osteolytic [62,79], although there have been some reports of lesions that are mixed blastic and lytic [80]. Interestingly, in a mouse model of breast cancer metastases to bone, Yi et al. found that inoculated MDA-MB-231 human triple negative breast cancer cells overexpressed platelet-derived growth factor-BB (PDGF-BB) causing partial osteosclerosis, or abnormal bone hardening, in mice [81]. In addition, breast cancer cells have also been found to produce endothelin-1 (ET-1), which activates osteoblast differentiation via suppression of dickkopf-1 (DKK-1) and increased wingless-related integration site (Wnt) signaling [82]. Exact mechanisms that elicit blastic lesions in bone metastatic breast cancer are not yet fully understood.

The vast majority of bone lesions that form as a result of metastatic breast cancer are lytic. As part of the well-described 'vicious cycle' of breast cancer metastases to bone, metastatic breast cancer cells produce parathyroid hormone related protein (PTHrP), which stimulates osteoblasts to produce increased amounts of RANK-L. RANK-L on the surface of osteoblasts binds to the receptor RANK on osteoclast precursors, stimulating osteoclastogenesis and increased bone resorption. Growth factors stored in bone are released, including insulin growth factor-1 (IGF-1) and TGF-beta, which are used by cancer cells to produce additional PTHrP (Figure 2) [83,84]. Bone resorption occurs at a rate greater than bone deposition. In fact, as part of a comprehensive analysis to determine the trafficking patterns of metastatic breast cancer cells to bone, Phadke et al. determined that osteoblasts located adjacent to metastatic breast cancer cells undergo apoptosis, resulting in the number of osteoblasts per bone surface being statistically decreased in late stage advanced disease with the presence of macrometastatic lesions. This finding correlated with a decrease in bone volume, but, interestingly, it was found that the number of TRAP+ osteoclasts also decreased upon formation of macrometastatic tumors [62]. These results suggest that in addition to diminished numbers of osteoblasts in late stages of bone metastatic breast cancer, the number of osteoclasts also decreases with increased tumor burden.

Clinically, patients with bone metastatic breast cancer and other lytic metastases are treated with drugs aimed at blocking the activity of osteoclasts, thereby slowing bone resorption. Bisphosphonate therapies such as denosumab [85], ibandronate [63,85,86], and zoledronic acid [87] alter osteoclast formation through either suppression of osteoblast-derived RANK-L, or increased expression of OPG, a decoy receptor for RANK-L. RANK-L binds to RANK receptor on immature osteoclasts to initiate osteoclastogenesis [88]. When present in the bone niche, RANK-L will bind to OPG instead of RANK receptor on immature osteoclasts [89]. In this way, increased expression of OPG leads to reduced osteoclastogenesis and bone degradation via alteration of the RANK-L/OPG ratio [89,90]. While these treatments slow the formation of new lesions, they are not curative for lesions already present [91,92]. Currently, there are no drugs available to stimulate osteoblast activity and bone 
deposition. Bisphosphonate therapies also do not prevent recurring metastases from forming. Bone pain, fractures, spinal cord compression, and hypercalcemia may result $[84,88,93]$.

\subsection{Multiple Myeloma Colonization of the Skeleton}

Multiple myeloma frequently metastasizes to bone [94]. Of patients presenting with multiple myeloma, approximately $70 \%$ of them have bone metastases upon diagnosis [95]. During the course of disease progression, over $90 \%$ of patients with multiple myeloma will develop skeletal lesions that are primarily osteolytic in nature [95]. During bone metastatic multiple myeloma, bone is resorbed at a rate faster than it is deposited resulting in increased formation of osteolytic lesions [95]. It has been demonstrated that metastatic multiple myeloma cells cause suppressed differentiation of osteoblasts from bone marrow mesenchymal stroma cells, leading to decreased bone deposition. Studies by the Roodman laboratory and others have demonstrated that multiple-myeloma-derived factors including interleukin-3 (IL-3) [96,97], sclerostin [98], TGF-beta [99,100], interleukin-7 (IL-7) [101], tumor necrosis factor-alpha (TNF-alpha) [101], DKK1 [102], and the zinc finger protein GFI1 [101] all contribute to suppression of osteoblast differentiation and bone deposition. Importantly, it was determined that bone metastatic multiple myeloma cells induce epigenetic changes at the RUNX2 locus which prevent osteoblasts from differentiating. Reduced expression of RUNX2 correlates with increased expression of GFI1 in osteoblast precursors [101]. Ectopic expression of GFI1 in osteoblasts leads to GFI1 binding to RUNX2, recruitment of the histone modifiers EZH2 and HDAC1, and reduced expression of RUNX2 in osteoblasts [103]. Knockdown of GFI1 in multiple myeloma cells was sufficient to reverse the recruitment of EZH2 and HDAC1, increase RUNX2 expression, and rescue osteoblast differentiation [103].

Clinically, therapeutic treatments for skeletal lesions as part of multiple myeloma bone disease have little impact on osteoblast function and thus bone repair, although life expectancy has been significantly improved [104]. Patient data suggests that osteolytic lesions rarely heal due to suppressed osteoblast differentiation even in patients with long-term complete remission of multiple myeloma bone disease [105]. Thus, there is a critical need for the development of therapeutic drugs that both target tumor progression as well as improve bone deposition via specific targeting of bone osteoblasts. As a start to this endeavor, Delgado-Calle et al. recently reported that use of genetic deletion of sclerostin, a potent Wnt/beta-catenin antagonist, prevents the loss of bone in a mouse model of multiple-myeloma-induced bone disease. Additionally, mouse treatment with an antibody to sclerostin led to reduced osteolytic lesion formation and increased bone volume in mice with multiple myeloma bone tumors [98]. Specifically, tumor-bearing mice deleted for sclerostin exhibited a $60 \%$ improvement in the number of osteolytic lesions and a $74 \%$ decrease in the area of osteolytic lesions compared to tumor-bearing wild-type mice. Furthermore, tumor-bearing mice deleted for sclerostin exhibited a 50\% increase in trabecular bone volume compared to tumor-bearing wild-type mice [98]. Most importantly, tumor-bearing mice deleted for sclerostin exhibited an increase in the number of osteoblasts, which correlated with an increase in bone formation when compared to tumor-bearing mice present for the gene. Osteoblast activity in tumor-bearing mice deleted for sclerostin remained at levels comparable to control mice injected with saline indicating rescue of osteoblast function in part by deletion of sclerostin [98]. Similarly, use of an antibody to sclerostin in tumor-bearing mice resulted in an increase in the number of osteoblasts/bone surface which correlated with increased trabecular bone volume [98]. These results suggest that inhibition of sclerostin may be a promising tool to promote bone deposition via increased osteoblast activity in multiple myeloma bone disease.

DKK1 is another inhibitor of osteoblast function that has been evaluated in recent clinical trials [106,107]. DKK1 has been found to inhibit the production of osteoblasts via preventing the binding of LRP5/6 to Wnt, thereby leading to a decrease in the expression of runt-related transcription factor-2 (RUNX2) in osteoblast precursors [108]. RUNX2 is a master regulator of osteoblast differentiation and function [109]. As part of a phase I/II clinical trial, an antibody to DKK1 was found to increase osteoblast differentiation in-vitro upon co-culture with multiple myeloma cells. In addition, 
there as a statistically significant increase in calcium deposition upon treatment with DKK1 antibody in co-cultures of pre-osteoblasts plus multiple myeloma cells [107]. These results suggest an increase in bone deposition. When used in a humanized mouse model with multiple myeloma-induced bone disease, a significant increase in the number of osteoblasts was observed as compared to untreated mice [107]. In addition, treatment with DKK1 antibody increased trabecular bone volume in tumor-bearing mice when compared to mice treated with placebo. Furthermore, treatment with the DKK1 antibody led to increased expression of Wnt/beta-catenin signaling, which is crucial for osteoblast differentiation, when compared to untreated mice [107]. Taken together these results suggest that inhibitors to DKK1 may be promising targeted therapeutics that promote osteoblast differentiation and subsequent bone deposition in patients with established multiple myeloma bone disease.

\subsection{Prostate Cancer Metastases to Bone}

Prostate cancer is another cancer type that frequently metastasizes to the bone. However, when compared to bone metastatic breast cancer and multiple myeloma-induced bone disease, lesions that result from bone metastatic prostate cancer can be either blastic, lytic, or mixed [110,111], though the majority of patients with bone metastatic prostate cancer present with osteoblastic lesions [112]. Blastic skeletal lesions that occur as a result of bone metastatic prostate cancer are named such due to their characteristic osteosclerotic, or hardened bone appearance on X-rays or CT scans [113]. When compared to patients with primarily lytic diseases, osteoblast production of markers such as alkaline phosphatase and procollagen C-propeptide are elevated in patients with bone metastatic prostate cancer. This is because prostate cancer cells preferentially home to osteoblast-rich regions of the bone, whereby direct contact between metastatic prostate cancer cells and osteoblasts leads to an increase in both osteoblast and prostate cancer cell proliferation [65,113]. Interestingly, studies by Sekita et al. determined that even though osteoblast proliferation was increased in bone metastatic prostate cancer, formation of an organized bone matrix was disrupted due to malalignment of osteoblasts along a collagen matrix. This led to production of bone with a spongeous structure as opposed to a compact lamellar structure. Disrupted bone matrix resulted in reduced bone toughness and impaired overall bone function [114,115].

Similar to the 'vicious cycle' of osteolytic bone metastases, bone metastases in prostate cancer enter into an autocatalytic cycle promoting both osteoblast proliferation and differentiation as well as metastatic prostate cancer cell proliferation. Bone metastatic prostate cancer cells secrete factors that promote osteoblast differentiation, including bone morphogenic proteins (BMPs), TGF-beta, IGF-1, platelet-derived growth factor, endothelin-1, and VEGF [8,93,116,117]. In turn, osteoblasts deposit new bone and matrix degradation is suppressed $[83,118]$. Activated osteoblasts additionally produce factors that stimulate prostate cancer cell proliferation including, VEGF, MCP-1, IL-6, and IL-8 (murine MIP-2) [119]. Osteolytic factors, including PTHrP additionally stimulate osteoblast differentiation and proliferation [120]. Furthermore, secretion of endothelin-1 by prostate cancer cells has been demonstrated to suppress DKK1, stimulating Wnt signaling and osteoblast bone deposition [121]. Thus, sustained bone formation occurs even in the presence of tumor growth. In addition to factors that promote osteoblast proliferation and differentiation, bone metastatic prostate cancer cells additionally express factors that stimulate osteoclastogenesis, including increased RANK-L and M-CSF. Activated osteoclasts resorb bone releasing growth factors including TGF-beta and IGF-1 which further stimulate prostate cancer growth [122].

Several agents are currently in clinical trials to combat blastic lesions produced during bone metastatic prostate cancer. These agents seek to reduce osteoblast bone deposition. Among them is atrasentan, an antagonist to the endothelin receptor A that seeks to reduce osteoblast differentiation and proliferation through blockade of endothelin receptor signaling and reduced Wnt signaling [121,123]. In a phase I/II clinical trial, use of the endothelin receptor A antagonist led to a reduction in bone pain and bone turnover, as well as slowed prostate tumor growth [124]. In phase II trials, patient treatment with atrasentan resulted in a significantly prolonged median time to disease progression when compared to placebo 
group [125]. These promising results led to a phase III trial which compared the use of atrasentan plus or minus docetaxel in patients with metastatic prostate cancer. Results of the phase III trial were unfortunately disappointing, whereby essentially no change was seen in median progression-free survival time or overall survival in patients treated with atrasentan plus docetaxel versus patients treated with docetaxel alone [126]. These results were similar to an earlier phase III clinical trial which sought to determine the efficacy of atrasentan in patients with metastatic hormone refractory prostate cancer [123]. In addition to atrasentan, radium-223 has been investigated as a treatment for patients with bone metastatic prostate cancer. Radium-223 is an alpha particle emitter that accumulates preferentially at sites with increased osteoblast activity and bone deposition [127]. In a mouse model of bone metastatic prostate cancer, tumor-bearing mice treated with radium-223 had reduced osteoblastic bone growth. In addition, osteoblasts found within tumor lesions exhibited double-stranded DNA breaks, suggesting disruption of new bone formation within tumor lesions. Moreover, use of radium-223 preserved bone volume and bone architecture [127]. Ongoing and future clinical trials will help to determine the optimal treatment modalities for patients with bone metastatic prostate cancer.

\section{Osteoblasts as Mediators in Cancer Cell Dormancy in Bone}

It is becoming increasingly evident that osteoblasts in the bone microenvironment play vital roles in cancer cell attraction [128,129], maintenance [50], and survival $[6,130,131]$ during cancer progression in bone. In particular, our laboratory previously demonstrated that osteoblasts are directed by bone metastatic breast cancer cells to increase osteoblast production of inflammatory cytokines implicated in cancer cell maintenance and survival [50]. Given that osteoblasts are directed by metastatic breast cancer cells in late stage disease to facilitate cancer cell survival in bone, we postulated that osteoblasts may also be involved in mediating events that occur during initial breast cancer cell bone dissemination. Our laboratory has evidence to suggest that crosstalk between osteoblasts and disseminated breast cancer cells elicits osteoblast production of factors that regulate breast cancer cell proliferation and survival in bone. Following extended exposure to breast cancer cells or their conditioned media, our laboratory demonstrated that exposed osteoblasts exhibit characteristics different from unexposed osteoblasts, including altered expression of cytokines and growth factors, including the proteins fractalkine and Axl (Figure 4), among others [132]. We call these exposed osteoblasts 'tumor-educated osteoblasts' (TEO).
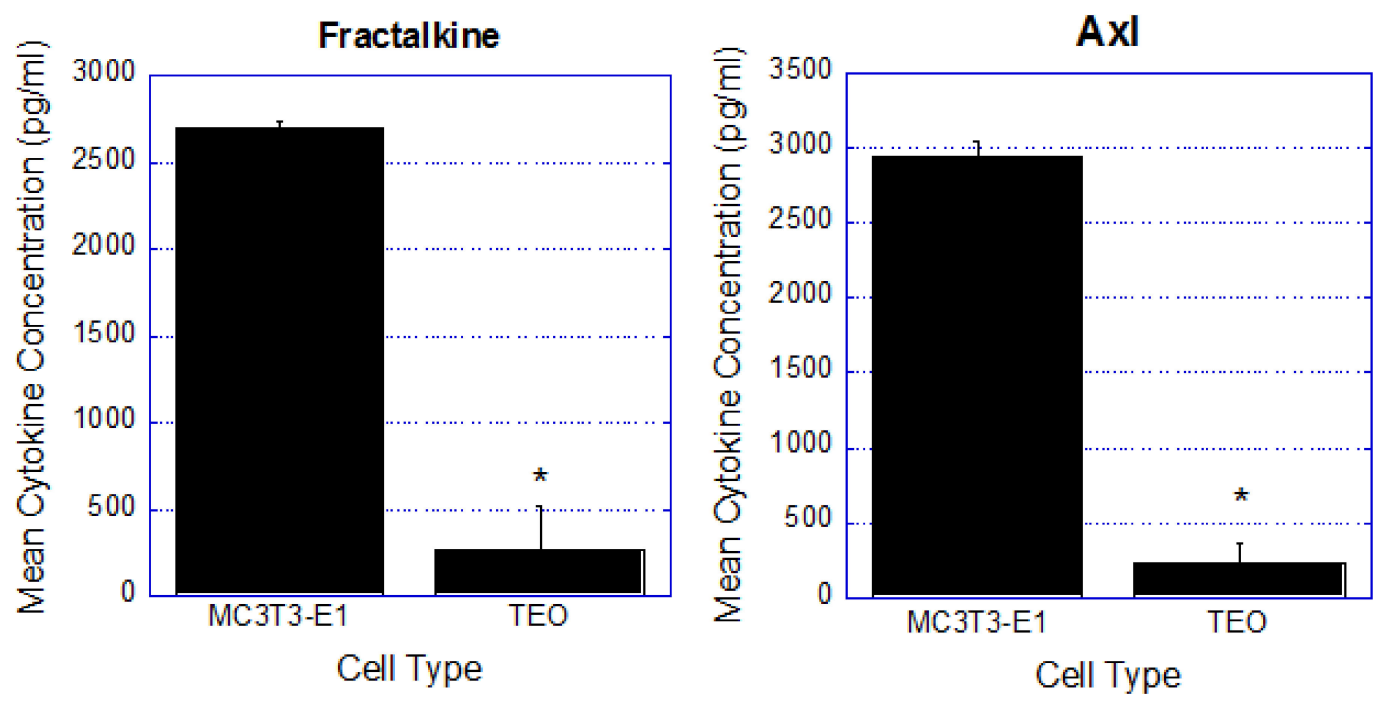

Figure 4. Tumor-educated osteoblast cells have altered cytokine production when compared to untreated osteoblasts. Conditioned media was prepared from untreated MC3T3-E1 osteoblasts or TEO cells and subjected to a RayBiotech Quantibody ${ }^{\circledR}$ Quantitative Multiplex ELISA Array. Three separate batches of conditioned media were assayed per condition. Shown are the mean protein concentration of Fractalkine and Axl produced by either untreated MC3T3-E1 osteoblasts or TEO cells. ${ }^{*} p<0.05$. 
Compared to unexposed osteoblasts, TEO cells produce decreased amounts of both fractalkine (11 fold decrease) and Axl (12 fold decrease) (Figure 4). Fractalkine produced by osteoblasts is known to be a chemoattractant for prostate cancer cells, as well as support prostate cancer cell migration and survival [133]. Fractalkine also plays a role in the dissemination of breast cancer cells to bone; and inhibiting the fractalkine receptor, CX3CR1, has been shown to reduce breast cancer cell bone dissemination and development of bone metastatic lesions [134,135]. Additionally, Axl is a receptor tyrosine kinase that has been described as a key player in cancer cell invasion and aggressiveness in bone [136]. Inhibition of Axl in triple negative breast cancer patient-derived xenograft models led to tumor growth inhibition and significantly reduced breast cancer metastasis to bone in-vivo [137]. When Axl was inhibited in cancer cells in-vitro, there was a reduction in genes associated with epithelial-mesenchymal transition (EMT) including SNAIL, VIM, and SLUG [137]. Furthermore, other laboratories have shown that cancer cells can direct stromal cells, including osteoblasts, to increase autocrine Gas6/ Axl signaling leading to increased cancer cell growth and survival in bone [138,139]. However, Jin, et al. demonstrated that inhibition of Gas6/Axl autocrine signaling in stromal cells abolishes paracrine signaling loops between cancer cells and stromal cells, leading to reduced cancer cell growth, and increased mouse survival [140].

Our laboratory additionally has evidence that TEO presence in tumors in-vivo leads to increased mouse time of survival and smaller tumors. When mice were injected with admixes of TEO cells plus human MDA-MB-231 breast cancer cells, mice lived, on average 20 days longer than mice inoculated with either an admix of unexposed osteoblasts plus MDA-MB-231 breast cancer cells, or MDA-MB-231 breast cancer cells alone (Figure 5A).

A)

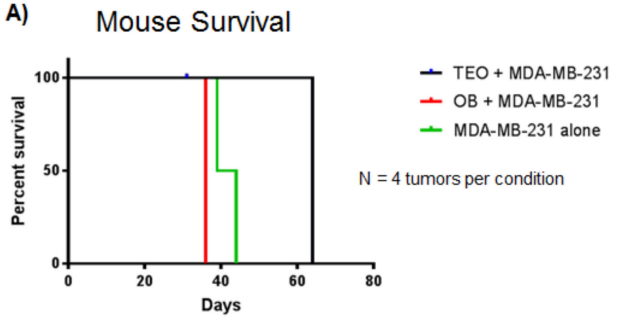

B)

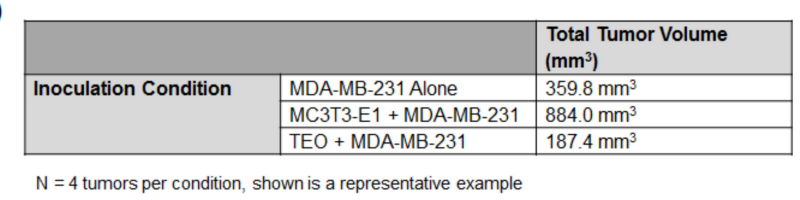

Figure 5. Mice inoculated with a mix of TEO cells plus MDA-MB-231 breast cancer cells lived longer and had smaller tumors than mice inoculated with a mix of untreated MC3T3-E1 cells plus MDA-MB-231 breast cancer cells, or breast cancer cells inoculated alone. Athymic nude mice were inoculated with either mixes of (1) TEO cells plus MDA-MB-231GFP breast cancer cells; (2) MC3T3-E1 osteoblasts plus MDA-MB-231GFP breast cancer cells; or (3) MDA-MB-231GFP breast cancer cells alone. (A) Kaplain-Meier Survival curve of percent mouse survival over time. Blue line, TEO plus MDA-MB-231GFP; red line, MC3T3-E1 plus MDA-MB-231GFP; green line, MDA-MB-231 cells alone. (B) Tumor size $\left(\mathrm{mm}^{3}\right)$. At least four mice were used per condition per time point. Shown are representative examples.

In addition, resultant tumors from mice inoculated with an admix of TEO cells plus breast cancer cells were nearly seven times smaller in volume when compared to tumors from admixes of unexposed osteoblasts plus breast cancer cells (Figure 5B). Furthermore, tumors composed of TEO cells were half the size of tumors formed by the injection of MDA-MB-231 cells alone (Figure 5B). These results suggest that TEO cells contribute to suppressed breast cancer cell proliferation in-vivo.

Other groups have investigated osteoblasts in the endosteal niche as contributors to prostate cancer or myeloma cell dormancy. Yumoto et al. demonstrated that co-culture of MC3T3-E1 osteoblasts plus either PC3 or DU145 prostate cancer cells resulted in a reduction of prostate cancer cell proliferation [136]. The authors found that this effect could be regulated by prostate cancer cell-derived Axl [136]. In addition, overexpression of the ligand to Axl, Gas6, increased expression of TGF-beta 2, which was found to mediate prostate cancer cell growth suppression in-vitro [136]. 
Furthermore, Yu-Lee and colleagues recently identified the osteoblast-derived factors GDF10 and TGF-beta 2 as a means by which prostate cancer cells are induced into a dormant state in bone [141]. When co-cultured with differentiated osteoblasts, C4-2B4, C4-2b, and PC3-mm2 prostate cancer cells were induced into a quiescent state, mediated by the proteins GDF10 and TGF-beta 2 [141]. The authors further determined that this effect occurred via activation of phospho-p38MAPK at S249/T252 sites [141]. In addition, Kobayashi et al. demonstrated that BMP7, as produced by osteoblasts and mesenchymal stromal cells, induces PC3 prostate cancer cell dormancy both in-vitro and in-vivo [142]. This effect was shown to be mediated via the p38-p21-NDRG1 signaling axis, whereby removal of BMP7, or knockdown of p21 or NDRG1 caused the cancer cells to fail to enter into dormancy [142]. Finally, when 5T33MM myeloma cells were co-cultured with either MC3T3-E1 osteoblasts or their conditioned media, myeloma cell proliferation was suppressed in-vitro [143]. These effects were in contrast to that seen when myeloma cells were treated with the conditioned media of osteoclast surrogates, which promoted myeloma cell proliferation [143]. Collectively, these results suggest that osteoblasts contribute to bone-disseminated cancer cell dormancy.

\section{Models to Study the Effect of the Bone Niche on Cancer Cell Dormancy}

Currently, there is no available model that fully recapitulates bone metastatic cancer cell dormancy as is evidenced in human disease. This is mainly due to extensive technical hurdles including, but not limited to, sustaining long-term cell growth of primary human stromal cells [144], recapitulating all steps in the tumor cell dissemination/metastatic cascade including cancer cell dormancy [145-147], and generation of models that permit the study of early events of initial cancer cell dissemination/seeding in bone $[145,146]$. Furthermore, current clinical evidence suggests that cancer cells can survive in a dormant state for decades in humans, only to be re-activated by mechanisms yet unknown $[64,148,149]$. There is no model available that recapitulates these events. Our laboratory and others have used several complementary approaches, including novel engineered organotypic models [144], cell lines [150,151], and extended culture bioreactors [151] to investigate cancer cell dormancy from multiple vantage points. For example, Ghajar et al. utilized 3D engineered bone marrow microvascular niches and zebrafish that contain a mutation of ectopic expression of a sprouting microvasculature to detect breast cancer cell quiescence versus growth [144]. This particular model permitted the study of early events that may occur during initial cancer cell dissemination and initiation of dormancy in a secondary microenvironment. In a clever way to overcome the technical challenges of endothelial cell growth in serum-free conditions, the authors transduced human umbilical vein endothelial cells with the gene E4ORF1, a human adenoviral gene that permits long-term cell survival [144]. In this way, the authors were able to successful generate a robust 3D microvasculature niche seeded with either lung fibroblasts or bone marrow mesenchymal stromal cells in order to study early interactions between weakly metastatic breast cancer cells (as surrogates for dormant cancer cells), stromal cells, and the vasculature [144]. In addition, Naumov et al. utilized D2.0R poorly metastatic mammary carcinoma cells as surrogates for dormant breast cancer cells to study breast cancer cell dissemination and dormancy in-vivo [150]. D2.0R cells were found to form metastases after extended periods of latency in the liver and other organs [150]. Thus, use of D2.0R cells permitted the study of cancer cells undergoing extended periods of latency (dormancy) in competent microenvironments in-vivo. In a later study, these same cells were used to study the growth characteristics of disseminated tumor cells upon their interaction with the extracellular matrix in-vivo [152]. Modifications to the extracellular matrix were later made, including increased deposition of type I collagen, which is frequently associated with fibrosis. These modifications then allowed the authors to study how the induction of fibrosis alters dormant cancer cell re-awakening and subsequent proliferation [153]. Finally, Sosnoski and colleagues utilized an extended, long-term bioreactor to engineer a bone-like microenvironment using mouse osteoblasts and a human metastasis-suppressed breast cancer cell line. This three-dimensional culture system permitted the authors to study long-term interactions (i.e., up to 1 year) between osteoblasts and dormant breast cancer cells [151], which is more representative of 
events that occur in humans. Furthermore, this model permitted the study of osteoblast-derived cytokines and their influence on dormant cancer cell growth [151]. While none of these models recapitulate the entirety of metastatic dormancy, they each shed light on important steps that occur during the process. Furthermore, use of these models permits focused study of specific elements that may contribute to cancer cell dormancy as well as early stages of the metastatic cascade.

Others have incorporated the use of specialized humanized bone microenvironments with which to study interactions between osteoblasts and breast cancer cells in cancer cell dormancy and metastasis in-vivo in an attempt to better recapitulate human disease. These methods include using irradiated human bone chip fragments that are capable of being seeded with cancer cells (including D2.0R cells as surrogates for dormant breast cancer cells [150]) plus stromal cells in Matrigel $^{\mathrm{TM}}$, thus generating a partial humanized bone microenvironment for implantation in-vivo [154]. Therefore, cells used as surrogates for dormant cancer cells may be seeded directly onto intact human bones, permitting the study of dormant cancer cell interaction with a physiologically relevant human matrix in-vivo. Thus, dormant cell migration and localization within the endosteal and hematopoietic bone niches might be more accurately assessed. This method was originally developed and refined by Andreeff and colleagues [154,155]. In a similar manner, implantable 3D printed biomaterial scaffolds are currently being used to generate humanized microenvironments in-vivo [156,157]. When compared to other non-human derived 3D models, bioprinted scaffolds provide the unique advantage of mimicking both bone structure/architecture and composition. These implants can become infiltrated with a vasculature similar to human bone [158]. Bioprinted scaffolds therefore permit the study of dormant cancer cell interaction with a matrix that mimics that of bone in-vivo. Furthermore, certain groups, including the Lee group, are incorporating the use of window chambers in mice to visualize cellular processes occurring on implanted scaffolds in real-time at the resolution of single cells [158,159]. Such models may permit real-time imaging of dormant cancer cell migration, invasion, and localization within the bone microenvironment. Similar to the human bone chips, bioprinted scaffolds can also be seeded with combinations of (dormant) cancer cells plus stromal cells in Matrigel ${ }^{\mathrm{TM}}$ [159]. Both of these methods allow for the use of specific (dormant) cancer cell lines (i.e., breast vs. prostate vs. multiple myeloma) to study relevant cancer cell-stromal cell (i.e., dormant cancer cell interactions with stromal cells of the endosteal niche) interactions. Recently, Weigelt et al. compiled a review of available 3D models to study interactions between stromal cells and breast cancer cells which can be found in [145].

\section{Dormant Cancer Cell Re-Activation in Bone}

The molecular mechanisms behind exit from dormancy are not well known, but are fundamental problems in tumor biology. Exit from dormancy can be influenced by many factors, including but not limited to, secretion of tumor-promoting signals, osteoclast activation, and extracellular matrix remodeling. Recent investigations have focused on cells in the endosteal niche as contributors to cancer cell re-activation in bone. In particular, Lawson et al. found that cells in the bone microenvironment, i.e., osteoblasts and osteoclasts, are capable of either promoting (osteoblasts) or dis-engaging (osteoclasts) myeloma cells from dormancy. When treated with the conditioned media of osteoclast-like RAW264.7 cells, 5T33 MM myeloma cells exhibited increased proliferation and growth [143]. In order to determine if this effect was caused by increased osteoclastogenesis in-vivo, the authors injected soluble RANK-L, which is commonly produced by osteoblasts in-vivo [160], into myeloma disease-bearing mice [143]. Daily administration of soluble RANK-L resulted in increased osteoclastogenesis and subsequent increased bone resorption. Interestingly, the authors observed that there was a reduction in the number of dormant myeloma cells in the bone upon increased bone resorption [143]. These results suggest that myeloma cancer cell re-activation is initiated by increased osteoclast activity as mediated by osteoblast-derived factors in bone. In a separate investigation examining mechanisms of dormancy in prostate cancer cells, reduction in osteoblast expression of TGF-beta and Gas6 led to a release from dormancy of PC3 and DU145 prostate cancer cells [136]. Furthermore, in a study by Kobayashi and colleagues, reduction of osteoblast- and 
mesenchymal stromal cell-derived BMP7 led to increased PC3 prostate cancer cell growth both in-vitro and in-vivo [142]. Therefore, these data suggest that osteoblasts are a key source of proteins, including RANK-L, TGF-beta, Gas6, and BMP7, that regulate dormant cancer cell re-activation in bone.

Additional studies have shown that direct interaction with osteoblasts and cells of the osteogenic niche reduce periods of breast cancer cell latency and promote cancer cell growth. In an investigation by Wang et al., when MCF-7 or MDA-MB-361 breast cancer cells were injected via intrailiac injection into mice, initial cancer cell colonization was slow for the first 2-4 weeks (MCF-7) or 4 months (MDA-MB-361) post-injection as evidenced by a lack of Ki67 staining and retention of an H2B-GFP label [161]. These results indicate a period of latency for the cancer cells, as defined as a "pre-osteolytic stage." However, upon direct interaction both in-vitro and in-vivo with either mouse MC3T3-E1 osteoblasts, human FOB1.19 fetal osteoblasts, or human mesenchymal stromal cells (in-vitro); or alkaline phosphatase, collagen-I, RUNX2, or osterix positive osteogenic niche cells (in-vivo), there was a statistically significant increase in breast cancer cell proliferation [161]. Proliferation effects were less pronounced when breast cancer cells were separated from the osteogenic cells using a Boyden Chamber assay. Additional experiments revealed that the osteogenic cells were interacting with the breast cancer cells via $\mathrm{N}$-cadherin and E-cadherin heterotypic adherens junctions, and that these interactions promoted breast cancer cell proliferation and escape from a latent, pre-osteolytic phase [161]. In fact, mice inoculated via intrailiac injection with MCF-7 cells, then treated with anti-E cadherin exhibited reduced cancer cell proliferation and less bone lesions [161]. Therefore, these results suggest that direct interaction with osteoblasts and osteogenic cells, such as mesenchymal stromal cells, may be one way in which latent breast cancer cells are released from dormancy in bone.

We would be remiss to not discuss an interesting study carried out by Gao and colleagues. Upon injection of $4 \mathrm{~T} 07$ breast cancer cells into the tail veins of mice, 4T07 cells infiltrated the lung, however remained quiescent and appeared solitary in number as evidenced in lung sections [162]. However, when 4 T07 cells were engineered to express Coco, a secreted inhibitor of TGF-beta, and injected into mice, single cells began to proliferate in the lung approximately 14 days post injection, such that by day 35, macrometastic lesions had formed in the lungs. These results suggest that Coco induces dormant cancer cell reactivation in the lung. Additional analyses demonstrated that reactivation of dormant breast cancer cells in the lung is caused by inhibition of BMP ligands via Coco [162]. Since bone osteoblasts highly express BMP ligands, it was next investigated whether this same phenomenon is found in bone. Interestingly, when Coco was silenced in 4T1 breast cancer cells that were inoculated via intracardiac injection into mice, no change was seen in cancer cell growth or lesion formation in bone [162]. These results are intriguing, given that BMP levels are typically high in bone, and BMPs (especially BMP-2) are required for osteoblast differentiation [163,164]. To further explore this result, the authors examined bone production of phospho-Sma-And Mad-Related Protein (also known as phospho-Mothers Against Decapentaplegic Homolog, or phospho-SMAD), a factor in the BMP-2/Smad signaling pathway [165]. While cells in the growth plate exhibited strong nuclear staining of phospho-SMAD, metastatic lesions detected in the bone were phospho-SMAD negative, which indicates that the lesions originated from phospho-SMAD negative cancer cells. By contrast, more than $94 \%$ of Coco responsive lesions in the lung were phospho-SMAD positive [162]. Therefore, these results suggest that while BMP signaling as mediated by osteoblasts in the bone may elicit dormant prostate cancer cell re-activation [142], mechanisms governing the process of cancer cell re-activation (A) may be dependent on the organ from which disseminated tumor cells originate (i.e., breast versus prostate), or (B) there may be subsets of dormant cancer cells not responsive to engagement of BMP proteins, and thus incapable of BMP-mediated re-activation. In the case of (B), this may suggest that dormant cancer cell re-activation is governed by multiple mechanisms, thus favoring a multi-modal clinical treatment approach to preventing indolent cell re-activation in cancer patients. 


\section{Osteoblasts in the Early Stages of Cancer Metastasis to Bone}

There is no model currently available that fully recapitulates the entirety of human metastasis to bone [155]. Efforts to study the early stages of disease progression, especially events that occur during initial cancer cell seeding in bone, have been hampered by lack of available mouse model systems, especially immuno-competent models, technical limitations, and lack of cell lines available that recapitulate all steps of disease progression [166]. As a result, our knowledge of early events of cancer metastases to bone is limited at best. A survey of the available literature revealed only two publications specifically dedicated to exploring the role of osteoblasts in early stage bone metastatic breast cancer $[167,168]$. Of these two, Bodenstine et al. sought to elucidate mechanisms that modulate osteoblast populations during early stage breast cancer bone metastasis [167]. The authors co-injected pre-osteoblast cells plus bone metastatic breast cancer cells via intratibial injection into mice and assessed tumor growth at 5 and 6 weeks post-inoculation. By 5 weeks post-inoculation, mice co-injected with osteoblasts plus breast cancer cells exhibited large, palpable tumors, that extended into the extra-osseous space, and which grew slightly by week 6 [167]. By comparison, tumors that formed in mice injected with cancer cells alone were half the size of those co-injected with osteoblasts, and remained contained in the bone. Osteolysis was found to occur in all treatment groups as exhibited by TRAP staining. The authors concluded that there is an important interaction between bone osteoblasts and metastatic breast cancer cells as evidenced by a dramatic increase seen in tumor size and growth into the extra-osseous space as compared to cancer cells injected alone [167]. While the time points studied and mouse models used may not be fully reflective of early events, they help shed light on communication that occurs between breast cancer cells and osteoblasts in bone. In the second publication, Scimeca et al. used patient samples consisting of breast infiltrating carcinomas, benign breast lesions, and bone metastatic lesions to identify the appearance of breast osteoblast-like cells in primary mammary lesions as an early predictor of breast cancer metastases to bone [168]. The authors found that there were a large number of breast cancer cells that underwent EMT in primary infiltrating carcinomas. This corresponded to a large number of breast-osteoblast-like cells found in the primary carcinomas that were positive for expression of RANK-L and vitamin D receptor. Intriguingly, breast osteoblast-like cells were also located in matched bone metastases. These results further suggest that crosstalk occurs between bone osteoblasts and metastatic breast cancer cells that may occur as early as when breast cancer cells are located in the primary site [168].

Wang et al. additionally carried out a study in an attempt to determine the involvement of osteoblasts in the early stages of bone metastatic prostate cancer [65]. The authors surmised that the distribution of cells of the osteoblast lineage may not be uniform within the bone, and that this may have important implications for cancer cell homing and adhesion during prostate cancer cell bone metastasis. This was in response to a study carried out by the Taichman group, suggesting that metastatic prostate cancer cells target hematopoietic stem cell niches in bone and compete with hematopoietic stem cells for development of prostate cancer bone metastases $[169,170]$. As per the Taichman group, the role of the osteoblast, in this case, was to maintain the hematopoietic stem cell niche as a reserve population in early stages of prostate cancer metastases to bone $[169,170]$. By way of the Wang study, mice were injected via intracardiac inoculation with bone-tropic prostate cancer cells. It was found that the prostate cancer cells preferentially homed to areas of the lateral endocortical bone regions, which were associated with 5-fold higher the number of bone osteoblasts compared to medial endocortical regions [65]. The authors also determined that the SDF-1/CXCR4 signaling axis was key to prostate cancer cell homing to these regions, as osteoblasts express the SDF-1 ligand and prostate cancer cells express the CXCR4 receptor. Use of the CXCR4 inhibitor AMD3100 disrupted the preferential homing of prostate cancer cells to the lateral endocortical region of bone [65]. Thus, these results suggest that prostate cancer cells preferentially home to osteoblast-rich areas in early stages of the disease. 


\section{The 'Vicious Cycle' of Cancer Metastasis to Bone}

Cancer metastases to bone disrupt the tightly regulated balance between osteoblasts and osteoclasts. Osteoblasts, in particular, unknowingly play important roles in fueling both (1) tumor cell growth and (2) sustained osteoclastogenesis and bone resorption. In a classic model of osteolytic metastasis proposed by Guise and Mundy, osteoblasts are stimulated to overproduce RANK-L by PTHrP as produced by breast cancer cells $[84,171,172]$. Osteoblast-secreted RANK-L binds the RANK receptor on osteoclast precursors, inducing osteoclast differentiation. Activated osteoclasts, in turn, secrete cathepsin $\mathrm{K}$ and other cysteine proteinases into the bone matrix, which help to degrade type I collagen, and ultimately result in bone matrix breakdown $[173,174]$. In addition, TGF-beta and IGF-1, released from the bone matrix, stimulate the cancer cells to produce additional PTHrP $[28,175]$. Furthermore, in addition to RANK-L dependent pathways, there is additional evidence to support RANK-L independent osteoclastogenesis via cancer-derived IL- 8 binding to IL-8 receptors on pre-osteoclasts [176]. In fact, Bendre et al. suggested that breast cancer-derived IL-8 may act earlier in the vicious cycle than tumor-derived PTHrP [177]. As a result of constitutive osteoclast activation and an inability of osteoblasts to lay down bone matrix, sustained bone degradation occurs $[178,179]$. This feedback establishes a 'vicious cycle', resulting in continued production of osteoclast initiating factors by osteoblasts, and constitutive activation of osteoclasts and osteolytic cancer cells (Figure 6).

Furthermore, similar to the 'vicious cycle' of osteolytic bone destruction in bone metastatic breast cancer, a similar mechanism has been described for occurrences in multiple myeloma. Multiple myeloma cells have been shown to produce factors that inhibit osteoblast differentiation and growth, including IL-3, TNF-alpha, and TGF-beta [180,181]. At the same time, multiple myeloma cells also produce factors that stimulate osteoclastogenesis including RANK-L, IL-6, MIP-1 alpha, and TNF-alpha [180,182-185]. Moreover, suppressed osteoblast activity also results in a reduction of osteoblast-derived OPG, a decoy receptor for RANK-L. The reduction in osteoblast bone deposition and increase in osteoclast bone resorption lead to sustained bone destruction which promotes disease progression [186].

In bone metastatic prostate cancer, similar mechanisms occur to that of lytic disease, however lesions that form are blastic due to sustained bone deposition. Metastatic prostate cancer cells produce increased amounts of endothelin-1 which causes sustained osteoblast differentiation [121]. In addition, DKK-1, a Wnt antagonist, is suppressed leading to increased osteoblast differentiation and proliferation [121]. Activated osteoblasts then produce increased amounts of growth factors including VEGF, IGF-1, and TGF-beta, which support cancer cell growth and proliferation $[93,116]$. Sustained bone deposition occurs at the same time as bone resorption [118] (Figure 6). Osteoblast bone matrix is laid down in a disorganized fashion, resulting in poorly developed, weak bone [114].

In years since the first description of the 'vicious cycle', several groups have added additional components to the classical model. Among them, Sethi et al. demonstrated that Jagged1, as expressed on tumor cells, can interact with both osteoblasts and pre-osteoclasts in the bone niche to further drive sustained bone resorption [163]. Specifically, Jagged1 was shown to bind to the receptor Notch on osteoblasts, leading to signaling through Rbpj and Hey1, and subsequent increased expression of osteoblast-derived IL-6 [60]. IL-6 in the tumor microenvironment has been demonstrated to be a potent driver of tumor cell growth [187]. In addition to binding Notch on osteoblasts, Jagged1 can also bind the Notch receptor on pre-osteoclasts, leading to increased osteoclastogenesis and the formation of mature osteoclasts capable of resorbing bone. Increased bone resorption by osteoclasts was found to release increased amounts of TGF-beta from the bone matrix, thus promoting tumor growth and survival [188].

Our group additionally found that IL-6, IL-8 (murine MIP-2), GRO-alpha (murine KC), MCP-1, and VEGF as produced by osteoblasts and found in their conditioned media enhanced osteoclast formation [50]. Importantly, IL-6, as administered to pre-osteoclasts in concentrations representative of that found in osteoblast conditioned media, led to the formation of TRAP+ osteoclasts [50]. Furthermore, IL6, IL-8, MCP-1, GRO-alpha, and VEGF were found to be maintenance and survival 
factors for bone metastatic breast cancer cells [50]. Therefore, osteoblast secretion of IL-6, IL-8, MCP-1, GRO-alpha, and VEGF contributes to osteoclast bone resorption independently of RANK-L in the classic 'vicious cycle' model, as well as promotes breast cancer survival in bone.

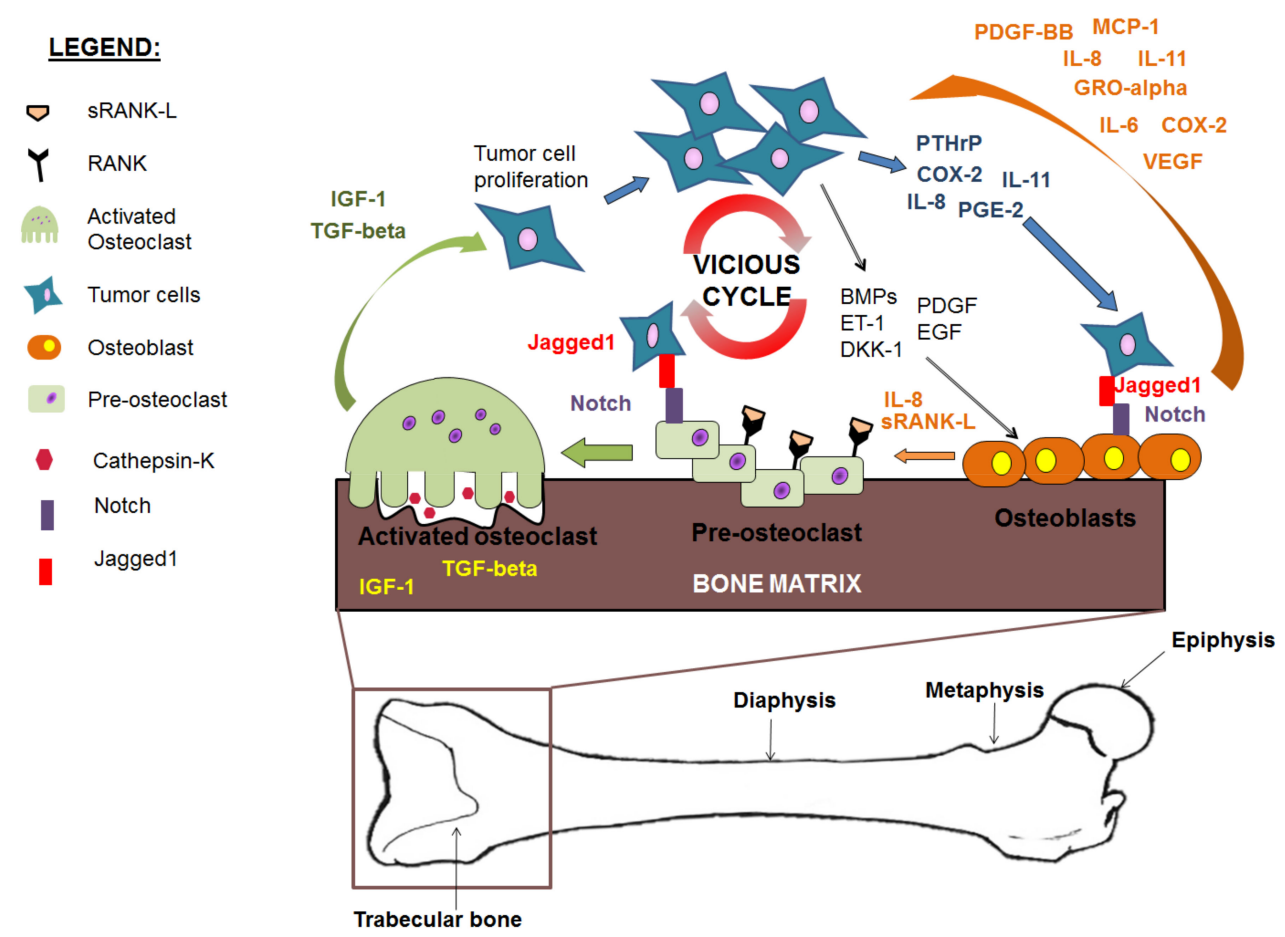

Figure 6. The 'Vicious Cycle' of bone degradation. In the 'vicious cycle' of cancer metastasis to bone, metastatic cancer cells produce parathyroid hormone related protein (PTHrP), interleukin-8 (IL-8), interleukin-11 (IL-11), prostaglandin E2 (PGE2), and cyclooxygenase-2 (COX-2) (lytic and blastic cancers) as well as bone morphogenic proteins (BMPs), endothelin-1 (ET-1), dickkopf-1 (DKK-1), platelet-derived growth factor (PDGF), and epidermal growth factor (EGF) (blastic cancers). These factors promote increased osteoblast production of interleukin-6 (IL-6), IL-8, monocyte chemoattractant protein-1 (MCP-1), vascular endothelial growth factor (VEGF), growth related oncogene-alpha (GRO-alpha), IL-11, and COX-2 that act as chemoattractants, maintenance, and survival factors for lytic metastatic cancer cells. Growth factors, including VEGF, insulin growth factor-1 (IGF-1), platelet-derived growth factor-BB (PDGF-BB), and tumor-growth factor-beta (TGF-beta) as produced by osteoblasts serve to promote proliferation of blastic cancers. Osteoblasts also produce increased amounts of soluble receptor activator of nuclear factor kappa beta-ligand (RANK-L), which binds to RANK receptors on pre-osteoclasts to initiate osteoclastogenesis. Furthermore, breast cancer cells that express Jagged1 ligand bind to the Notch receptor on osteoblasts leading to increased osteoblast-derived RANK-L expression and increased osteoclast activation. Jagged1 expressing breast cancer cells can also bind to the Notch receptor on pre-osteoclasts and initiate osteoclastogenesis independent of RANK-L. Activated osteoclasts resorb bone by secretion of proteases including cathepsin K into resorption pits, and release TGF-beta and IGF-1 from the bone matrix. TGF-beta and IGF-1 act on metastatic tumor cells to promote proliferation and continued expression of PTHrP, IL-8, IL-11, PGE2, COX-2, BMPs, ET-1, DKK-1, PDGF, and EGF from cancer cells.

Furthermore, cyclooxygenase-2 (COX2) as expressed by both osteoblasts [204] and breast cancer cells [199] has been demonstrated to facilitate the formation of a microenvironment favorable for cancer cell growth and survival. In a study by Singh, et al. overexpression of breast cancer cell-derived COX2 led to an increase in cancer cell invasion and metastasis in a mouse model of breast cancer metastasis to bone [199]. Increased COX2 lead to increased expression of both PGE2 and IL-8 in breast cancer cells, and especially breast cancer cells with bone tropism [196]. Moreover, COX2 was found 
to mediate the production of interleukin-11 (IL-11), up to a 6-fold increase, in triple negative, ER+, and bone-seeking metastatic breast cancer cells [206]. Since both IL-11 and IL-8 as produced by both osteoblasts [50,193] and breast cancer cells [177,197] have been shown to stimulate osteoclastogenesis both by RANK-L dependent and independent mechanisms [176,177,197,221], a system favoring increased COX2 expression would lead to increased osteolytic metastases and thus further drive the 'vicious cycle' of breast cancer bone metastases. These findings as a whole have been summarized in Figure 6 and Table 1.

Table 1. Sources of important factors produced by osteoblasts, osteoclasts, or bone metastatic cancer cells in the 'vicious cycle' of bone degradation.

\begin{tabular}{cccc}
\hline Factor & Osteoblast & Osteoclast & Cancer Cells \\
\hline IL-6 & {$[50,60,189,190]$} & - & {$[50,191]$} \\
IL-8 & {$[50,176,192,193]$} & {$[176]$} & {$[176,177,194-197]$} \\
MCP-1 & {$[50,198,199]$} & - & - \\
VEGF & {$[50,130,131]$} & - & {$[50,200,201]$} \\
GRO-alpha & {$[50]$} & - & - \\
COX-2 & {$[202-204]$} & - & {$[196,199,205,206]$} \\
TGF-beta & {$[129,175]$} & {$[207,208]$} & - \\
IGF-1 & {$[175]$} & {$[19,209]$} & - \\
PTHrP & - & - & {$[28,84,175,210,211]$} \\
IL-11 & {$[193]$} & - & {$[177,197,206,212]$} \\
PGE-2 & {$[213]$} & - & {$[196,214]$} \\
Cathepsin-K & - & {$[173,174,215]$} & - \\
Jagged-1 & - & - & {$[188,216]$} \\
Notch-1 & {$[216]$} & {$[188]$} & - \\
RANK-L & {$[84,172]$} & - & - \\
RANK & - & {$[84,172]$} & - \\
Endothelin-1 & {$[217]$} & - & {$[121,217]$} \\
DKK-1 & - & - & {$[121,218-220]$} \\
\hline
\end{tabular}

Cells of the bone microenvironment produce factors in response to bone metastatic breast cancer cells. The cell sources of key factors produced are listed. The dash indicates we were unable to find evidence in the literature that the molecule was produced by the indicated cell type.

\section{Osteoblasts in Advanced Stage Metastatic Disease}

There has been extensive evidence in recent years demonstrating the role of osteoblasts in late stage bone metastatic cancers. By way of crosstalk with bone metastatic cancer cells, osteoblasts are diverted from synthesizing bone matrix to producing proteins that play vital roles in cancer cell attraction [128,129], maintenance [50], and survival $[6,130,131]$ during cancer progression in bone. Specifically, we showed that osteoblasts are a key source of cytokines necessary for metastatic breast cancer cell maintenance and survival in bone. When either co-cultured with MDA-MB-231 metastatic breast cancer cells or treated with their conditioned media, we found that osteoblasts increased their production of the inflammatory cytokines IL-6, IL-8, and MCP-1 [51]. It is well documented that these cytokines are capable of initiating osteoclastogenesis, as well as are capable of increasing the activity of osteoclasts $[176,177,196,222-224]$. In a follow-up study, we additionally found that osteoblasts were key sources of VEGF and GRO-alpha (mouse KC) when in the presence of metastatic breast cancer cells [50]. Similar results were seen when we examined both early (10 days) and late (20 day) differentiated osteoblasts, although effects were more pronounced (higher statistical significance) upon metastatic breast cancer cell co-culture or conditioned media treatment with late differentiated osteoblasts (20 days differentiated) [50]. Most importantly, we found that, in comparison to differentiated osteoblasts, breast cancer cells expressed negligible amounts ( $\sim 3 \mathrm{pg} / \mathrm{mL})$ of MCP-1, a chemokine involved in inflammation [225]. Osteoblasts, however, expressed comparably larger amounts of MCP-1 ( 2 ng/mL), which was increased up to 7 fold upon treatment with breast cancer conditioned medium [50]. MCP-1 has been demonstrated as being important for cancer cell proliferation, migration, and invasion [226-229]. Thus, these results imply that bone 
metastatic breast cancer cells rely on osteoblast production of MCP-1 as a key factor for their oncogenic properties in bone. In addition, when MDA-MB-231 metastatic breast cancer cells were inoculated via intracardiac injection into athymic nude mice, we observed an increase in bone-derived cytokine production in disease-bearing mice [50]. Interestingly, we found that the increase in bone cell-derived cytokine production was the most pronounced in the metaphyseal ends, as opposed to the diaphysis, of murine femurs [50]. Immunochemistry revealed that the osteoblast-derived cytokines VEGF and MCP-1 were specifically localized to bone ends composed of trabecular bone and not the bone shaft in non-cancer bearing mice [130]. IL-6 was found to be localized to the bone marrow [130]. Importantly, osteoblast conditioned media was a potent chemoattractant for metastatic breast cancer cells and also elicited the formation of TRAP+ osteoclasts [50]. Thus, these results demonstrate that breast cancer cells utilize osteoblast-derived cytokines to facilitate breast cancer cell colonization and survival in the bone microenvironment. These results additionally show that the osteoblast-derived cytokines IL-6, MCP-1, IL-8 (mouse MIP-2), GRO-alpha (mouse KC), and VEGF are also capable of stimulating osteoclastogenesis either in addition to or in the absence of the RANKL-RANK pathway [50]. Our findings additionally extend the 'vicious cycle' of bone degradation to include the cytokines IL-6, MCP-1, IL-8 (mouse MIP-2), GRO-alpha (mouse KC), and VEGF as produced by osteoblasts [50] (Figure 6). In addition to these effects, we found that osteoblasts had altered morphology, exhibited decreased expression of alkaline phosphatase, osteocalcin, and bone sialoprotein in-vitro, as well as underwent apoptosis in-vivo when adjacent to bone metastatic breast cancer cells in situations of advanced tumor burden [28,179,230].

In addition to effects in bone metastatic breast cancer, it has been demonstrated that osteoblasts and osteoblast-derived factors also have metastasis-promoting effects in bone metastatic prostate cancer. In a study by Karlsson and colleagues, osteoblast-derived TGF-beta, among other factors, was shown to increase PC-3U prostate cancer cell migration as well as formation of pro-migratory protrusions [129]. In a series of experiments by the Taichman group, osteoblast-derived CXCL12 (SDF-1) was found to mediate bone metastatic prostate cancer progression via binding of its receptor CXCR4 on the prostate cancer cells. CXCL12 was additionally found to be highly expressed in the skeleton, and was localized to the ends of long bones; areas to which bone metastatic cancer cells preferentially traffic $[62,128,231,232]$. In addition, Lee et al. determined that osteoblast expression of c-met and VEGFR2 promoted PC-3 and C4-2B prostate cancer cell growth in bone, as well as increased osteoclastogenesis and osteolytic lesion formation [131]. Inhibition of osteoblast-derived c-Met and VEGFR2 or mouse treatment with cabozantinib, a tyrosine kinase inhibitor with a high affinity for c-Met and VEGFR2 [190], led to a reduction in bone metastatic prostate tumor growth, and also reduced osteoblast production of RANKL and M-CSF, two factors necessary for osteoclastogenesis [131]. On the other hand, another group determined that treatment with cabozantinib may in fact lead to osteoblast upregulation of factors that promote bone metastatic prostate cancer cell migration and survival. Primary mouse osteoblasts were treated with $100 \mathrm{nM}$ of cabozantinib and their proliferation and differentiation analyzed. It was found that while treatment with cabozantinib led to a decrease in osteoblast proliferation, osteoblast differentiation, as measured by alkaline phosphatase and osteocalcin expression, as well as osteoblast mineralization were significantly increased [233]. Further analysis revealed that increased osteoblast differentiation led to an increase in the osteoblast-derived factors IGFBP2 and WNT16, among others [233]. These factors have been shown in the literature to stimulate anchorage independent cancer cell growth [234], and have been linked to therapeutic resistance in cancer [235]. When PC3-mm2 or C42B4 prostate cancer cells were treated with the conditioned media of cabozantinib treated osteoblasts, there was an increase in anchorage independent prostate cancer cell growth as well as an increase in prostate cancer cell migration [233]. Overall, these data suggest that factors produced by osteoblasts promote metastatic prostate cancer progression in bone.

A similar role has recently emerged for osteoblasts in the progression of multiple myeloma in bone. In a study by van Andel et al., it was discovered that osteoblasts express R-spondins which promote Wnt signaling in an leucine rich repeat containing G protein-coupled receptor-4 (LGR4)-dependent manner in multiple myeloma cells [236]. Multiple myeloma cells were found to 
have aberrant LGR4 signaling, and thus were capable of increased sensitivity to Wnt signaling [236]. Incidentally, activation of the canonical Wnt signaling pathway in multiple myeloma cells helped to drive cancer cell proliferation, and was associated with increased cancer cell dissemination to bone, increased disease progression, and increased therapeutic resistance $[237,238]$. In addition, Nemani et al. determined that multiple myeloma cells initiate osteoblasts to reduce their expression of decorin, a extracellular matrix proteoglycan with tumor suppressive properties [239]. Multiple myeloma induced suppression of decorin in osteoblasts was found to be mediated by chemokine (C-C motif) ligand-3 (CCL3). When decorin was reduced in osteoblasts, this promoted multiple myeloma cell proliferation and survival [239].

Clinically, patients with osteolytic metastases are treated with drugs that block osteoclast activity. Therapies utilizing drugs called bisphosphonates, such as pamidronate, prevent osteoclast bone resorption by inducing osteoclast apoptosis. Pamidronate binds to and adsorbs to hydroxyapatite crystals in the bone matrix. Osteoclasts ingest the drug as they degrade bone. Farnesylation and geranylgeranylation of proteins necessary for osteoclast function are inhibited, and osteoclasts undergo apoptosis [240]. Pamidronate does not inhibit bone mineralization or formation [240]. By reducing osteoclast-mediated bone resorption, pamidronic acid decreases the rate of bone turnover, stabilizes the bone matrix, and reduces hypercalcemia. While pamidronate is a treatment for bone metastatic breast cancer by blocking osteoclast activity, it is not curative [91,241]. Lesion progression is slowed, but pre-existing lesions do not heal $[92,178,242,243]$. There are currently no treatments that specifically target osteoblasts to reduce osteoblast apoptosis or promote bone deposition. Severe bone pain, fractures, hypercalcemia, and spinal cord compression may also occur due to sustained bone resorption $[83,84,244,245]$. The inability of bone to regenerate following bisphosphonate treatment suggests that bone metastatic breast cancer cells alter osteoblast function in addition to constitutive activation of osteoclasts.

There has, however, been encouraging data recently examining use of the tyrosine kinase inhibitor, cabozantinib, as an indirect anti-tumor agent and direct modulator of osteoblasts. Several groups have recently demonstrated that cabozantinib is capable of specifically targeting bone osteoblasts to decrease their production of RANK-L and increase their production of the RANK-L decoy receptor OPG. As a direct result of altered ratio of RANK-L/OPG, osteoclastogenesis decreased and osteoblast numbers increased compared to control [246,247]. In mice, administration of cabozantinib reduced prostate cancer cell proliferation in bone and induced prostate cancer cell apoptosis [248]. A different study also revealed that tumor growth was suppressed, along with a reduction in the formation of bone-resorbing osteoclasts via a decrease in osteoblast-derived RANKL and M-CSF in a mouse model of bone metastatic prostate cancer [131]. Intriguingly, however, use of cabozantinib in patients with advanced metastatic castration-resistant prostate cancer as part of the COMET- 1 and COMET-2 phase III clinical trials did not extend overall patient survival as compared to the treatments prednisone or prednisone plus mitoxantrone [249]. Over 1000 patients were followed as part of this analysis [249]. A small benefit from cabozantinib was seen, however, towards improvement in bone scan response, radiographic progression-free survival, and reduction in symptomatic skeletal events in patients with advanced metastatic castration-resistant prostate cancer as part of the COMET-1 trial [250]. Furthermore, patient treatment with cabozantinib led to increased expression of alkaline phosphatase and cross-linked type I collagen, suggesting increased osteoblast differentiation and bone matrix organization [250]. These results were similar to in-vitro studies which showed that primary mouse osteoblast treatment with cabozantinib resulted in increased osteoblast expression of alkaline phosphatase [233].

As previously mentioned, bisphosphonate drug therapy does not cure osteolytic lesions. One possibility for this occurrence is that breast cancer cells affect osteoblast differentiation. Osteoblasts develop from osteoprogenitor cells, which undergo a program of differentiation to become mature, functional osteoblasts capable of synthesizing bone matrix [21]. Work by Mercer et al. demonstrated that culturing mouse osteoblasts with conditioned medium from a human metastatic 
breast cancer cell line inhibited expression of osteoblast differentiation markers and completely blocked the ability of osteoblasts to mineralize bone matrix [179]. Since osteoblasts do not differentiate properly in the presence of breast cancer cells, it is possible that the cancer cells may alter the overall protein secretion profile of osteoblasts. This alteration may prevent osteoblasts from producing the differentiation proteins necessary for developing into mature, bone-depositing cells, as well as by inducing production of cytokines that contribute to the progression of bone metastasis, increase activation of osteoclasts, and contribute to the formation of osteolytic lesions.

\section{Osteoblast Alignment and Bone Matrix Organization Are Altered by Direct Interaction with Bone Metastatic Cancer Cells}

In recent years, there have been a number of reports demonstrating correlations between bone matrix organization, strength, and the involvement of bone osteoblasts. A recent report by Matsugaki et al. demonstrated the importance of the alignment of osteoblasts in the bone matrix toward preserving tissue microstructure [115]. When compared to a control surface, the authors determined that, on an abnormally arranged surface, osteoblasts aligned themselves orthogonal to the direction of artificial matrix. This orientation caused the osteoblasts to form elongated f-actin stress fibers perpendicular to matrix collagen stress fibers and crystals of biological apatite [115]. Incidentally, this abnormal orientation of osteoblasts, and associated disorganized matrix, directly reflects that seen in tumor-bearing bones. In fact, direct interaction with bone metastatic prostate, breast, or multiple myeloma cells led to disorganized arrangement of osteoblasts along with subsequent disruption of the alignment of collagen fibers and biological apatite in the long bones of tumor-bearing mice [114,251]. This effect was not seen when osteoblasts were treated with cancer cell conditioned medium, suggesting that soluble cancer-derived factors play no role in modulating osteoblast orientation within the tumor microenvironment [251]. Furthermore, during co-culture with cancer cells, osteoblasts increased their production of cadherin-11, a protein that promotes cell-cell and cell-substrate adhesion as well as regulates collagen synthesis [252,253], and connexin-43 [251], a ubiquitous connexin that functions in the formation of gap junctions [254]. These results suggest that alteration of osteoblast alignment in the bone matrix upon direct interaction with bone metastatic cancer cells may be mediated by gap junction signaling or cell-cell adhesion molecules.

Osteoblast arrangement within bone determines the bone matrix microstructure, including alignment of both biological apatite and collagen fibers [114,115,251]. It has been determined that alignment of biological apatite is strongly correlated to Young's modulus, or the ability of a material to withstand changes in longitudinal compression or tension [255]. In addition, collagen fiber orientation in bone was correlated with bone toughness [256]. Importantly, loss of mechanical function within bone is associated with malalignment of the bone matrix, contributing to diseases such as osteoporosis and cancer-induced bone disease [257]. Thus, as a whole, these results suggest that increased malalignment of osteoblasts, as a result of direct interaction with bone metastatic cancer cells, causes disrupted formation of the bone matrix, including disorganized arrangement of biological apatite and collagen fibers, and reduced mechanical function. Moreover, reduced bone mechanical function correlates with both reduced bone toughness and reduced capacity to withstand longitudinal forces of tension or compression [114]. These structural changes further contribute to overall bone degradation in bone metastatic cancers.

\section{Cancer Cells Are Capable of Mimicking Osteoblasts in the Tumor Microenvironment}

In addition to cancer cells modifying osteoblast functions, one of the most devious actions cancer cells can take is that of osteomimicry. In order to better survive in the bone microenvironment, bone metastatic cancer cells pay osteoblasts the ultimate form of flattery in an attempt to resemble a resident osteoblast bone cell. There are documented reports of bone metastatic cancer cells producing normal bone turnover markers such as alkaline phosphatase, and markers of bone remodeling such as MMPs and collagen [258-260]. To make matters worse, the cancer cells produce increased amounts 
of factors that fuel bone resorption, including MMPs, which further contribute to the 'vicious cycle of bone degradation' [261]. Tan and colleagues conducted an interesting study to determine ways breast cancer cells may be transformed into osteoblast-like cells in the bone. After undergoing an epithelial-mesenchymal transition, as stimulated by the conditioned media from cancer-associated fibroblasts, MCF-7 and T47D breast cancer cells were then stimulated with BMP2 to induce an osteoblast-like phenotype [259]. Compared to untreated breast cancer cells, treated breast cancer cells increased their expression of osteoblast cadherin CDH11, RUNX2, osteonectin (SPARC), the bone matrix-remodeling protein periostin, as well as a defined set of "bone-related genes". These effects were not observed in untreated breast cancer cells [259]. These results suggest that breast cancer cells are capable of undergoing osteomimicry after EMT, and express factors that are master mediators of bone remodeling signaling pathways typically found in osteoblasts. Furthermore, a study by Hagberg Thulin et al. revealed that treatment with osteoblast conditioned media increased LNCaP-19 and LNCaP prostate cancer cell expression of osteoblast-like genes, including RUNX2, MMP2, CDH11, osteonectin, and osteopontin [260]. Furthermore, in a study by Hassan et al., it was demonstrated that upon differentiation, osteoblasts normally express microRNA-218 in the bone microenvironment [258]. MiR-218 was found to have potent osteogenic properties, including enhancement of osteoblast differentiation and mineralization, as well as increased osteoblast lineage commitment of bone marrow progenitor cells. Interestingly, miR-218 expression in metastatic breast cancer cells leads to abnormal expression of genes associated with osteomimicry which promote cancer cell homing to bone, including the chemokine receptor CXCR4 [258]. Moreover, treatment with miR-218 also increased bone metastatic breast cancer cell expression of genes associated with normal osteoblast bone turnover including bone sialoprotein and osteopontin [258]. Finally, Graham et al. demonstrated that PC-3 and C4-2B bone metastatic prostate cancer cell lines have enhanced bone invasive properties as compared to LNCaP cells [262]. PC-3 and C4-2B enhanced bone metastatic potential was found to be due to increased cancer cell expression of the osteoblast-like factors type IA collagen, osteocalcin, and osteopontin. These effects could be enhanced in the PC-3 and C4-2B prostate cancer cells by BMP-2 [262]. Thus, these results as a whole suggest that osteomimicry, or acquisition of an osteoblast-like phenotype, may be a way that cancer cells specifically traffic to the bone microenvironment and further create a suitable secondary niche supportive of cancer cell growth and survival.

\section{Future Questions to Be Considered}

Even though substantial progress has been made in the past decade towards understanding metastatic cancer cell progression in bone, many questions remain. It is clear that bone metastatic cancer cells hijack endogenous cells of the bone and exploit normal processes in order to favor cancer cell maintenance and survival. What is the mechanistic 'tipping point' that permits switching from 'normal' bone remodeling processes to promoting cancer progression? As previously discussed, Lawson et al. found that disseminated cancer cell entry into dormancy may be a reversible state, and that promotion of dormancy may occur via interactions with osteoblasts and cells of the osteogenic lineage [143]. Exit from dormancy was postulated to occur by function of increased osteoclast bone resorption of the niche, suggesting that better understanding of interplay between dormant cancer cells and the molecular mechanisms involved in active bone remodeling may be keys to controlling entry and exit from dormancy. More importantly, if osteoblasts are capable of inducing cancer cell dormancy in early stages of the disease, is it possible for that capability to be exploited in order to induce a perpetual state of cancer cell proliferative quiescence in bone? To that point, Wang et al. demonstrated that prostate cancer cells preferentially seed in osteoblast-rich areas of bone, and in some cases were found in direct contact with osteoblasts, especially in lateral endocortical regions of bone as opposed to medial regions [65]. This was primarily evident in the early stages of cancer cell homing to bone; however the authors noted that preferential seeding of osteoblast-rich areas also occurred at later times of up to 3 weeks in a mouse model of intracardiac injection [65]. We also demonstrated a similar trend of metastatic breast cancer cell seeding in bone, whereby metastatic breast cancer cells 
injected into mice via the intracardiac route preferentially homed to and seeded in (1) the metaphyseal regions of long bones, areas of high bone turnover, and (2) the endosteal marrow of long bones are opposed to central marrow [62]. These data not only emphasize the importance of bone remodeling in cancer cell homing, seeding, and dormancy in bone, but also that osteoblasts, in particular, might be one of the keys to control of these processes.

What event(s) cause osteoblasts to switch from "dormancy-promoting" to "metastasis-promoting"? While Lawson et al. described that increased osteoclast activity and bone resorption might be one way in which cancer cells exit dormancy [143], it is unclear how cancer cells are capable of remaining in a dormant state for decades even though there is routine bone turnover. Is it necessary for an adverse event on a larger scale, such as a fracture, or perhaps osteopenia, to occur before exit from dormancy via bone remodeling can occur? Similarly, might it be that exit from dormancy can only occur in situations where there may be a temporary increase in bone resorption in excess of bone deposition? Do these changes need to local (as in the case of a fracture) versus systemic (as in the case of osteopenia) in bone to elicit escape from dormancy via bone remodeling? These questions have yet to be elucidated. Furthermore, are there specific osteoblast- or bone-derived biomarkers that may be capable of indicating which patients harbor dormant cancer cells in their bones? In light of data provided by Wang et al. [65], these markers may include alterations in osteoblast markers such as alkaline phosphatase, BMPs, or even master regulators of osteoblast function such as RUNX2. And, are there biomarkers to indicate which patients will progress to metastatic disease prior to the formation of occult macrometastatic lesions? Again, based on evidence by Lawson, the answer to this question may be, in part, directly related to the balance between bone deposition and bone resorption, whereby sustained bone resorption marked by elevated levels of calcium and growth factors stored in bone such as TGF-beta and IGF-1 might be early indicators of disease advancement [143]. If biomarkers are discovered to indicate dormant bone disease, might there be a method to attack and eliminate sleeping cancer cells in bone prior to the development of occult lesion formation? And, might there be a way to sensitize dormant cancer cells to chemotherapeutic treatments? Further investigations are needed to study the intricacies of bone remodeling, including direct interplay between osteoblasts, osteoclasts, and cancer cells, in order to elucidate mechanisms of crosstalk in cancer cell dormancy and progression in bone.

\section{Conclusions}

The bone microenvironment is a fertile 'soil' for metastatic cancer cells (the 'seeds') and it is evident that the 'soil' is extremely influential in facilitating cancer cell 'seed' growth. Crosstalk between cells of the bone, especially the bone osteoblasts, and cancer cells drives cancer cell progression and metastasis in the bone microenvironment. It is becoming increasingly evident that osteoblasts in the bone are major regulators of cancer cell bone progression and metastasis. Osteoblasts clearly play key roles in functioning as 'tumor-suppressors' versus 'tumor-promoters' during different stages of bone metastatic cancer. Indeed, it is intriguing to consider that osteoblasts may possess this dual role during cancer cell progression in bone. Furthermore, as of yet, there have been no data to describe what mechanisms govern the balance between osteoblast 'dormancy-promoting' versus osteoblast 'metastasis-promoting' functions. The available data currently point towards bone-disseminated cancer cells as master manipulators to this process. However, might it be possible to selectively promote osteoblast functions that permit cancer cell dormancy yet resist cancer cell reawakening? Understanding the mechanisms behind osteoblast involvement in these events will lead to a better understanding of cancer cell dissemination to bone, as well as progression to metastatic disease, and will also aid in the development of therapeutic drugs to block the development of macrometastatic lesions in bone.

Author Contributions: K.M.B. conceived, designed, wrote, edited, and revised the manuscript. A.D.K., A.B.S., and D.M. wrote the manuscript and contributed to the figures. 
Acknowledgments: This work was supported by NIH, NCI K99/R00 Pathway to Independence Grant R00 CA178177 and Pennsylvania State Department of Health 4100072566 for KMB.

Conflicts of Interest: The authors declare no conflict of interest.

\section{References}

1. Marks, S.C., Jr.; Odgren, P.R. Structure and development of the skeleton. In Principles of Bone Biology; Bilezikian, J.P., Raisz, L.G., Rodan, G.A., Eds.; Academic Press: San Diego, CA, USA, 2002; Volume 1, pp. 3-16.

2. Alberts, B.; Johnson, A.; Lewis, J.; Raff, M.; Roberts, K.; Walter, P. Molecular Biology of the Cell; Garland Science: New York, NY, USA, 2002.

3. Augat, P.; Schorlemmer, S. The role of cortical bone and its microstructure in bone strength. Age Ageing 2006, 35 (Suppl. 2), ii27-ii31. [CrossRef] [PubMed]

4. Nakano, T.; Kaibara, K.; Tabata, Y.; Nagata, N.; Enomoto, S.; Marukawa, E.; Umakoshi, Y. Unique alignment and texture of biological apatite crystallites in typical calcified tissues analyzed by microbeam $\mathrm{x}$-ray diffractometer system. Bone 2002, 31, 479-487. [CrossRef]

5. Keaveny, T.M.; Morgan, E.F.; Niebur, G.L.; Yeh, O.C. Biomechanics of trabecular bone. Annu. Rev. Biomed. Eng. 2001, 3, 307-333. [CrossRef] [PubMed]

6. Bussard, K.M.; Gay, C.V.; Mastro, A.M. The bone microenvironment in metastasis; what is special about bone? Cancer Metastasis Rev. 2008, 27, 41-55. [CrossRef] [PubMed]

7. Roodman, G.D. Mechanisms of bone metastasis. N. Engl. J. Med. 2004, 350, 1655-1664. [CrossRef] [PubMed]

8. Logothetis, C.J.; Lin, S.H. Osteoblasts in prostate cancer metastasis to bone. Nat. Rev. Cancer 2005, 5, 21-28. [CrossRef] [PubMed]

9. U.S. National Institutes of Health, N.C.I. Seer Training Modules, Cancer Registration E Surveillance Modules: Classificatoin of Bones. Available online: https:/ / training.seer.cancer.gov (accessed on 5 May 2018).

10. Florencio-Silva, R.; Sasso, G.R.; Sasso-Cerri, E.; Simoes, M.J.; Cerri, P.S. Biology of bone tissue: Structure, function, and factors that influence bone cells. BioMed Res. Int. 2015, 2015, 421746. [CrossRef] [PubMed]

11. Oftadeh, R.; Perez-Viloria, M.; Villa-Camacho, J.C.; Vaziri, A.; Nazarian, A. Biomechanics and mechanobiology of trabecular bone: A review. J. Biomech. Eng. 2015, 137. [CrossRef] [PubMed]

12. Price, J.S.; Oyajobi, B.O.; Russell, R.G. The cell biology of bone growth. Eur. J. Clin. Nutr. 1994, 48 (Suppl. 1), S131-S149. [PubMed]

13. Mazo, I.B.; von Andrian, U.H. Adhesion and homing of blood-borne cells in bone marrow microvessels. J. Leukoc. Biol. 1999, 66, 25-32. [CrossRef] [PubMed]

14. Capulli, M.; Paone, R.; Rucci, N. Osteoblast and osteocyte: Games without frontiers. Arch. Biochem. Biophys. 2014, 561, 3-12. [CrossRef] [PubMed]

15. Bonewald, L.F. The amazing osteocyte. J. Bone Miner. Res. 2011, 26, 229-238. [CrossRef] [PubMed]

16. Mullender, M.G.; van der Meer, D.D.; Huiskes, R.; Lips, P. Osteocyte density changes in aging and osteoporosis. Bone 1996, 18, 109-113. [CrossRef]

17. Takahashi, N.; Udagawa, N.; Takami, M.; Suda, T. Cells of bone: Osteoclast generation. In Principles of Bone Biology; Bilezikian, J.P., Raisz, L.G., Rodan, G.A., Eds.; Academic Press: San Diego, CA, USA, 2002; Volume 1, pp. 109-126.

18. Stenbeck, G. Formation and function of the ruffled border in osteoclasts. Semin. Cell Dev. Biol. 2002, 13, 285-292. [CrossRef] [PubMed]

19. Hauschka, P.V.; Mavrakos, A.E.; Iafrati, M.D.; Doleman, S.E.; Klagsburn, M. Growth factors in bone matrix. Isolation of multiple types by affinity chromatography on heparin-sepharose. J. Biol. Chem. 1986, 261, 12665-12674. [PubMed]

20. Minguell, J.J.; Erices, A.; Conget, P. Mesenchymal stem cells. Exp. Biol. Med. 2001, 226, 507-520. [CrossRef]

21. Lian, J.B.; Stein, G.S. Concepts of osteoblast growth and differentiation: Basis for modulation of bone cell development and tissue formation. Crit. Rev. Oral Biol. Med. 1992, 3, 269-305. [CrossRef] [PubMed]

22. Renema, N.; Navet, B.; Heymann, M.F.; Lezot, F.; Heymann, D. Rank-rankl signalling in cancer. Biosci. Rep. 2016, 36, e00366. [CrossRef] [PubMed]

23. Amarasekara, D.S.; Yun, H.; Kim, S.; Lee, N.; Kim, H.; Rho, J. Regulation of osteoclast differentiation by cytokine networks. Immune Netw. 2018, 18, e8. [CrossRef] [PubMed] 
24. Ren, H.; Ren, H.; Li, X.; Yu, D.; Mu, S.; Chen, Z.; Fu, Q. Effects of intermedin on proliferation, apoptosis and the expression of opg/rankl/m-csf in the mc3t3-e1 osteoblast cell line. Mol. Med. Rep. 2015, 12, 6711-6717. [CrossRef] [PubMed]

25. Kanis, J.A.; McCloskey, E.V. Bone turnover and biochemical markers in malignancy. Cancer 1997, 80, 1538-1545. [CrossRef]

26. Wilson, S.R.; Peters, C.; Saftig, P.; Bromme, D. Cathepsin k activity-dependent regulation of osteoclast actin ring. J. Biol. Chem. 2009, 284, 2584-2592. [CrossRef] [PubMed]

27. Blair, H.C. How the osteoclast degrades bone. Bioessays 1998, 20, 837-846. [CrossRef]

28. Mastro, A.M.; Gay, C.V.; Welch, D.R.; Donahue, H.J.; Jewell, J.; Mercer, R.; DiGirolamo, D.; Chislock, E.M.; Guttridge, K. Breast cancer cells induce osteoblast apoptosis: A possible contributor to bone degradation. J. Cell. Biochem. 2004, 91, 265-276. [CrossRef] [PubMed]

29. Josse, J.; Velard, F.; Gangloff, S.C. Staphylococcus aureus vs. Osteoblast: Relationship and consequences in osteomyelitis. Front. Cell. Infect. Microbiol. 2015, 5, 85. [CrossRef] [PubMed]

30. Sanchez, C.; Deberg, M.A.; Bellahcene, A.; Castronovo, V.; Msika, P.; Delcour, J.P.; Crielaard, J.M.; Henrotin, Y.E. Phenotypic characterization of osteoblasts from the sclerotic zones of osteoarthritic subchondral bone. Arthritis Rheum. 2008, 58, 442-455. [CrossRef] [PubMed]

31. Sanchez, C.; Mazzucchelli, G.; Lambert, C.; Comblain, F.; DePauw, E.; Henrotin, Y. Comparison of secretome from osteoblasts derived from sclerotic versus non-sclerotic subchondral bone in oa: A pilot study. PLoS ONE 2018, 13, e0194591. [CrossRef] [PubMed]

32. Yoneda, T. Mechanisms of preferential metastasis of breast cancer to bone. Int. J. Oncol. 1996, 9, $103-109$. [CrossRef] [PubMed]

33. Hamza, T.; Li, B. Differential responses of osteoblasts and macrophages upon Staphylococcus aureus infection. BMC Microbiol. 2014, 14, 207. [CrossRef] [PubMed]

34. Weber, A.; Chan, P.M.B.; Wen, C. Do immune cells lead the way in subchondral bone disturbance in osteoarthritis? Prog. Biophys. Mol. Biol. 2017. [CrossRef] [PubMed]

35. Tofino-Vian, M.; Guillen, M.I.; Perez Del Caz, M.D.; Castejon, M.A.; Alcaraz, M.J. Extracellular vesicles from adipose-derived mesenchymal stem cells downregulate senescence features in osteoarthritic osteoblasts. Oxid. Med. Cell. Longev. 2017, 2017, 7197598. [CrossRef] [PubMed]

36. Lentino, J.R. Prosthetic joint infections: Bane of orthopedists, challenge for infectious disease specialists. Clin. Infect. Dis. 2003, 36, 1157-1161. [CrossRef] [PubMed]

37. Berendt, T.; Byren, I. Bone and joint infection. Clin. Med. 2004, 4, 510-518. [CrossRef]

38. Tillander, J.; Hagberg, K.; Berlin, O.; Hagberg, L.; Branemark, R. Osteomyelitis risk in patients with transfemoral amputations treated with osseointegration prostheses. Clin. Orthop. Relat. Res. 2017, 475, 3100-3108. [CrossRef] [PubMed]

39. Kellesarian, S.V.; Javed, F.; Romanos, G.E. Osteomyelitis arising around osseointegrated dental implants: A systematic review. Implant Dent. 2018. [CrossRef] [PubMed]

40. Semel, G.; Wolff, A.; Shilo, D.; Akrish, S.; Emodi, O.; Rachmiel, A. Mandibular osteomyelitis associated with dental implants. A case series. Eur. J. Oral Implantol. 2016, 9, 435-442. [PubMed]

41. Heilmann, C. Adhesion mechanisms of staphylococci. Adv. Exp. Med. Biol. 2011, 715, 105-123. [PubMed]

42. Bosse, M.J.; Gruber, H.E.; Ramp, W.K. Internalization of bacteria by osteoblasts in a patient with recurrent, long-term osteomyelitis. A case report. J. Bone Jt. Surg. Am. 2005, 87, 1343-1347. [CrossRef]

43. Dapunt, U.; Maurer, S.; Giese, T.; Gaida, M.M.; Hansch, G.M. The macrophage inflammatory proteins mip1alpha (ccl3) and mip2alpha (cxcl2) in implant-associated osteomyelitis: Linking inflammation to bone degradation. Mediat. Inflamm. 2014, 2014, 728619. [CrossRef] [PubMed]

44. Bost, K.L.; Bento, J.L.; Ellington, J.K.; Marriott, I.; Hudson, M.C. Induction of colony-stimulating factor expression following staphylococcus or salmonella interaction with mouse or human osteoblasts. Infect. Immun. 2000, 68, 5075-5083. [CrossRef] [PubMed]

45. Wright, K.M.; Friedland, J.S. Regulation of chemokine gene expression and secretion in staphylococcus aureus-infected osteoblasts. Microbes Infect. 2004, 6, 844-852. [CrossRef] [PubMed]

46. Ning, R.; Zhang, X.; Guo, X.; Li, Q. Staphylococcus aureus regulates secretion of interleukin-6 and monocyte chemoattractant protein-1 through activation of nuclear factor kappab signaling pathway in human osteoblasts. Braz. J. Infect. Dis. 2011, 15, 189-194. [PubMed] 
47. Gasper, N.A.; Petty, C.C.; Schrum, L.W.; Marriott, I.; Bost, K.L. Bacterium-induced cxcl10 secretion by osteoblasts can be mediated in part through toll-like receptor 4. Infect. Immun. 2002, 70, 4075-4082. [CrossRef] [PubMed]

48. Somayaji, S.N.; Ritchie, S.; Sahraei, M.; Marriott, I.; Hudson, M.C. Staphylococcus aureus induces expression of receptor activator of nf-kappab ligand and prostaglandin e2 in infected murine osteoblasts. Infect. Immun. 2008, 76, 5120-5126. [CrossRef] [PubMed]

49. Widaa, A.; Claro, T.; Foster, T.J.; O'Brien, F.J.; Kerrigan, S.W. Staphylococcus aureus protein a plays a critical role in mediating bone destruction and bone loss in osteomyelitis. PLoS ONE 2012, 7, e40586. [CrossRef] [PubMed]

50. Bussard, K.M.; Venzon, D.J.; Mastro, A.M. Osteoblasts are a major source of inflammatory cytokines in the tumor microenvironment of bone metastatic breast cancer. J. Cell. Biochem. 2010, 111, 1138-1148. [CrossRef] [PubMed]

51. Kinder, M.; Chislock, E.M.; Bussard, K.M.; Shuman, L.A.; Mastro, A.M. Metastatic breast cancer induces an osteoblast inflammatory response. Exp. Cell Res. 2008, 314, 173-183. [CrossRef] [PubMed]

52. Sosnoski, D.; Krishnan, V.; Kraemer, W.J.; Dunn-Lewis, C.; Mastro, A.M. Changes in cytokines of the bone microenvironment during breast cancer metastasis. Int. J. Breast Cancer 2012, 2012, 160265. [CrossRef] [PubMed]

53. Claro, T.; Widaa, A.; O'Seaghdha, M.; Miajlovic, H.; Foster, T.J.; O’Brien, F.J.; Kerrigan, S.W. Staphylococcus aureus protein a binds to osteoblasts and triggers signals that weaken bone in osteomyelitis. PLOS ONE 2011, 6, e18748. [CrossRef] [PubMed]

54. Sanchez, C.J., Jr.; Ward, C.L.; Romano, D.R.; Hurtgen, B.J.; Hardy, S.K.; Woodbury, R.L.; Trevino, A.V.; Rathbone, C.R.; Wenke, J.C. Staphylococcus aureus biofilms decrease osteoblast viability, inhibits osteogenic differentiation, and increases bone resorption in vitro. BMC Musculoskelet. Disord. 2013, 14, 187. [CrossRef] [PubMed]

55. Rasigade, J.P.; Trouillet-Assant, S.; Ferry, T.; Diep, B.A.; Sapin, A.; Lhoste, Y.; Ranfaing, J.; Badiou, C.; Benito, Y.; Bes, M.; et al. Psms of hypervirulent staphylococcus aureus act as intracellular toxins that kill infected osteoblasts. PLoS ONE 2013, 8, e63176. [CrossRef] [PubMed]

56. Fitzgerald, K.A.; O’Neill, L.A.J.; Gearing, A.J.H.; Callard, R.E. The Cytokine Facts Book, 2nd ed.; Academic Press: San Diego, CA, USA, 2001.

57. Sanchez, C.; Pesesse, L.; Gabay, O.; Delcour, J.P.; Msika, P.; Baudouin, C.; Henrotin, Y.E. Regulation of subchondral bone osteoblast metabolism by cyclic compression. Arthritis Rheum. 2012, 64, 1193-1203. [CrossRef] [PubMed]

58. Bianco, D.; Todorov, A.; Cengic, T.; Pagenstert, G.; Scharen, S.; Netzer, C.; Hugle, T.; Geurts, J. Alterations of subchondral bone progenitor cells in human knee and hip osteoarthritis lead to a bone sclerosis phenotype. Int. J. Mol. Sci. 2018, 19, 475. [CrossRef] [PubMed]

59. Martineau, X.; Abed, E.; Martel-Pelletier, J.; Pelletier, J.P.; Lajeunesse, D. Alteration of wnt5a expression and of the non-canonical wnt/pcp and wnt/pkc-ca2+ pathways in human osteoarthritis osteoblasts. PLoS ONE 2017, 12, e0180711. [CrossRef] [PubMed]

60. Tat, S.K.; Padrines, M.; Theoleyre, S.; Couillaud-Battaglia, S.; Heymann, D.; Redini, F.; Fortun, Y. Opg/membranous-Rankl complex is internalized via the clathrin pathway before a lysosomal and a proteasomal degradation. Bone 2006, 39, 706-715. [CrossRef] [PubMed]

61. Paget, S. The distribution of secondary growths in cancer of the breast. Lancet 1889, 133, 571-573. [CrossRef]

62. Phadke, P.A.; Mercer, R.R.; Harms, J.F.; Yujiang, J.; Frost, A.R.; Jewell, J.L.; Bussard, K.M.; Nelson, S.; Moore, C.; Kappes, J.C.; et al. Kinetics of metastatic breast cancer cell trafficking in bone. Clin. Cancer Res. 2006, 12, 1431-1440. [CrossRef] [PubMed]

63. Geng, C.-J.; Liang, Q.; Zhong, J.-H.; Zhu, M.; Meng, F.-Y.; Wu, N.; Liang, R.; Yuan, B.-Y. Ibandronate to treat skeletal-related events and bone pain in metastatic bone disease or multiple myeloma: A meta-analysis of randomised clinical trials. BMJ Open 2015, 5, e007258. [CrossRef] [PubMed]

64. Sosa, M.S.; Bragado, P.; Aguirre-Ghiso, J.A. Mechanisms of disseminated cancer cell dormancy: An awakening field. Nat. Rev. Cancer 2014, 14, 611-622. [CrossRef] [PubMed]

65. Wang, N.; Docherty, F.E.; Brown, H.K.; Reeves, K.J.; Fowles, A.C.; Ottewell, P.D.; Dear, T.N.; Holen, I.; Croucher, P.I.; Eaton, C.L. Prostate cancer cells preferentially home to osteoblast-rich areas in the early stages 
of bone metastasis: Evidence from in vivo models. J. Bone Miner. Res. 2014, 29, 2688-2696. [CrossRef] [PubMed]

66. Belic, J.; Graf, R.; Bauernhofer, T.; Cherkas, Y.; Ulz, P.; Waldispuehl-Geigl, J.; Perakis, S.; Gormley, M.; Patel, J.; $\mathrm{Li}, \mathrm{W}$; et al. Genomic alterations in plasma DNA from patients with metastasized prostate cancer receiving abiraterone or enzalutamide. Int. J. Cancer 2018. [CrossRef] [PubMed]

67. Pulido, C.; Vendrell, I.; Ferreira, A.R.; Casimiro, S.; Mansinho, A.; Alho, I.; Costa, L. Bone metastasis risk factors in breast cancer. Ecancermedicalscience 2017, 11, 715. [CrossRef] [PubMed]

68. Greenberg, A.J.; Rajkumar, S.V.; Therneau, T.M.; Singh, P.P.; Dispenzieri, A.; Kumar, S.K. Relationship between initial clinical presentation and the molecular cytogenetic classification of myeloma. Leukemia 2014, 28, 398-403. [CrossRef] [PubMed]

69. Santini, D.; Barni, S.; Intagliata, S.; Falcone, A.; Ferraù, F.; Galetta, D.; Moscetti, L.; La Verde, N.; Ibrahim, T.; Petrelli, F.; et al. Corrigendum: Natural history of non-small-cell lung cancer with bone metastases. Sci. Rep. 2016, 6, 22205. [CrossRef] [PubMed]

70. Daniele, S.; Sandro, B.; Salvatore, I.; Alfredo, F.; Francesco, F.; Domenico, G.; Luca, M.; Nicla, L.V.; Toni, I.; Fausto, P.; et al. Natural history of non-small-cell lung cancer with bone metastases. Sci. Rep. 2015, 5, 18670.

71. Kim, S.; Chun, M.; Wang, H.; Cho, S.; Oh, Y.-T.; Kang, S.-H.; Yang, J. Bone metastasis from primary hepatocellular carcinoma: Characteristics of soft tissue formation. Cancer Res. Treat. 2007, 39, 104-108. [CrossRef] [PubMed]

72. Chen, S.-C.; Kuo, P.-L. Bone metastasis from renal cell carcinoma. Int. J. Mol. Sci. 2016, 17, 987. [CrossRef] [PubMed]

73. Durante, C.; Haddy, N.; Baudin, E.; Leboulleux, S.; Hartl, D.; Travagli, J.P.; Caillou, B.; Ricard, M.; Lumbroso, J.D.; De Vathaire, F; et al. Long-term outcome of 444 patients with distant metastases from papillary and follicular thyroid carcinoma: Benefits and limits of radioiodine therapy. J. Clin. Endocrinol. Metab. 2006, 91, 2892-2899. [CrossRef] [PubMed]

74. Kennecke, H.; Yerushalmi, R.; Woods, R.; Cheang, M.C.; Voduc, D.; Speers, C.H.; Nielsen, T.O.; Gelmon, K. Metastatic behavior of breast cancer subtypes. J. Clin. Oncol. 2010, 28, 3271-3277. [CrossRef] [PubMed]

75. Liede, A.; Jerzak, K.J.; Hernandez, R.K.; Wade, S.W.; Sun, P.; Narod, S.A. The incidence of bone metastasis after early-stage breast cancer in canada. Breast Cancer Res. Treat. 2016, 156, 587-595. [CrossRef] [PubMed]

76. Siegel, R.L.; Miller, K.D.; Jemal, A. Cancer statistics, 2018. CA Cancer J. Clin. 2018, 68, 7-30. [CrossRef] [PubMed]

77. Lipton, A.; Uzzo, R.; Amato, R.J.; Ellis, G.K.; Hakimian, B.; Roodman, G.D.; Smith, M.R. The science and practice of bone health in oncology: Managing bone loss and metastasis in patients with solid tumors. J. Natl. Compr. Cancer Netw. 2009, 7 (Suppl. 7), S1-S29. [CrossRef]

78. Manders, K.; van de Poll-Franse, L.V.; Creemers, G.J.; Vreugdenhil, G.; van der Sangen, M.J.; Nieuwenhuijzen, G.A.; Roumen, R.M.; Voogd, A.C. Clinical management of women with metastatic breast cancer: A descriptive study according to age group. BMC Cancer 2006, 6, 179. [CrossRef] [PubMed]

79. Mundy, G.R. Bone Remodeling and Its Disorders; Martin Dunitz Ltd.: London, UK, 1999.

80. Coleman, R.E. Skeletal complications of malignancy. Cancer 1997, 80, 1588-1594. [CrossRef]

81. Yi, B.; Williams, P.J.; Niewolna, M.; Wang, Y.; Yoneda, T. Tumor-derived platelet-derived growth factor-bb plays a critical role in osteosclerotic bone metastasis in an animal model of human breast cancer. Cancer Res. 2002, 62, 917-923. [PubMed]

82. Yin, J.J.; Mohammad, K.S.; Kakonen, S.M.; Harris, S.; Wu-Wong, J.R.; Wessale, J.L.; Padley, R.J.; Garrett, I.R.; Chirgwin, J.M.; Guise, T.A. A causal role for endothelin-1 in the pathogenesis of osteoblastic bone metastases. Proc. Natl. Acad. Sci. USA 2003, 100, 10954-10959. [CrossRef] [PubMed]

83. Guise, T.A.; Mundy, G.R. Cancer and bone. Endocr. Rev. 1998, 19, 18-54. [CrossRef] [PubMed]

84. Mundy, G.R. Metastasis to bone: Causes, consequences and therapeutic opportunities. Nat. Rev. Cancer 2002, 2, 584-593. [CrossRef] [PubMed]

85. Marathe, D.D.; Marathe, A.; Mager, D.E. Integrated model for denosumab and ibandronate pharmacodynamics in postmenopausal women. Biopharm. Drug Dispos. 2011, 32, 471-481. [CrossRef] [PubMed]

86. Anagnostis, P.; Vakalopoulou, S.; Christoulas, D.; Paschou, S.A.; Papatheodorou, A.; Garipidou, V.; Kokkoris, P.; Terpos, E. The role of sclerostin/dickkopf-1 and receptor activator of nuclear factor kb 
ligand/osteoprotegerin signalling pathways in the development of osteoporosis in patients with haemophilia a and b: A cross-sectional study. Haemoph. Off. J. World Fed. Hemoph. 2018, 24, 316-322. [CrossRef] [PubMed]

87. Tu, K.N.; Lie, J.D.; Wan, C.K.V.; Cameron, M.; Austel, A.G.; Nguyen, J.K.; Van, K.; Hyun, D. Osteoporosis: A review of treatment options. Pharm. Ther. 2018, 43, 92-104.

88. Guise, T.A. Molecular mechanisms of osteolytic bone metastases. Cancer 2000, 88, 2892-2898. [CrossRef]

89. Udagawa, N.; Takahashi, N.; Yasuda, H.; Mizuno, A.; Itoh, K.; Ueno, Y.; Shinki, T.; Gillespie, M.T.; Martin, T.J.; Higashio, K.; et al. Osteoprotegerin produced by osteoblasts is an important regulator in osteoclast development and function. Endocrinology 2000, 141, 3478-3484. [CrossRef] [PubMed]

90. Boyce, B.F.; Xing, L. Biology of rank, rankl, and osteoprotegerin. Arthritis Res. Ther. 2007, 9 (Suppl. 1), S1. [CrossRef] [PubMed]

91. Hiraga, T.; Williams, P.J.; Mundy, G.R. The bisphosphonate ibandronate promotes apoptosis in mda-mb-231 human breast cancer cells in bone metastases. Cancer Res. 2001, 61, 4418-4424. [PubMed]

92. Taube, T.; Elomaa, I.; Blomqvist, C.; Benton, N.C.; Kanis, J.A. Histomorphometric evidence for osteoclast-mediated bone resorption in metastatic breast cancer. Bone 1994, 15, 161-166. [CrossRef]

93. Guise, T.A.; Mohammad, K.S.; Clines, G.; Stebbins, E.G.; Wong, D.H.; Higgins, L.S.; Vessella, R.; Corey, E.; Padalecki, S.; Suva, L.; et al. Basic mechanisms responsible for osteolytic and osteoblastic bone metastases. Clin. Cancer Res. 2006, 12, 6213s-6216s. [CrossRef] [PubMed]

94. Marino, S.; Roodman, G.D. Multiple myeloma and bone: The fatal interaction. Cold Spring Harbor Perspect. Med. 2017. [CrossRef] [PubMed]

95. Bataille, R.; Chappard, D.; Marcelli, C.; Dessauw, P.; Sany, J.; Baldet, P.; Alexandre, C. Mechanisms of bone destruction in multiple myeloma: The importance of an unbalanced process in determining the severity of lytic bone disease. J. Clin. Oncol. 1989, 7, 1909-1914. [CrossRef] [PubMed]

96. Ehrlich, L.A.; Chung, H.Y.; Ghobrial, I.; Choi, S.J.; Morandi, F.; Colla, S.; Rizzoli, V.; Roodman, G.D.; Giuliani, N. Il-3 is a potential inhibitor of osteoblast differentiation in multiple myeloma. Blood 2005, 106, 1407-1414. [CrossRef] [PubMed]

97. Silbermann, R.; Bolzoni, M.; Storti, P.; Guasco, D.; Bonomini, S.; Zhou, D.; Wu, J.; Anderson, J.L.; Windle, J.J.; Aversa, F.; et al. Bone marrow monocyte-/macrophage-derived activin a mediates the osteoclastogenic effect of il-3 in multiple myeloma. Leukemia 2014, 28, 951-954. [CrossRef] [PubMed]

98. Delgado-Calle, J.; Anderson, J.; Cregor, M.D.; Condon, K.W.; Kuhstoss, S.A.; Plotkin, L.I.; Bellido, T.; Roodman, G.D. Genetic deletion of sost or pharmacological inhibition of sclerostin prevent multiple myeloma-induced bone disease without affecting tumor growth. Leukemia 2017, 31, 2686-2694. [CrossRef] [PubMed]

99. Waning, D.L.; Mohammad, K.S.; Reiken, S.; Xie, W.; Andersson, D.C.; John, S.; Chiechi, A.; Wright, L.E.; Umanskaya, A.; Niewolna, M.; et al. Excess tgf-beta mediates muscle weakness associated with bone metastases in mice. Nat. Med. 2015, 21, 1262-1271. [CrossRef] [PubMed]

100. Nyman, J.S.; Merkel, A.R.; Uppuganti, S.; Nayak, B.; Rowland, B.; Makowski, A.J.; Oyajobi, B.O.; Sterling, J.A. Combined treatment with a transforming growth factor beta inhibitor (1d11) and bortezomib improves bone architecture in a mouse model of myeloma-induced bone disease. Bone 2016, 91, 81-91. [CrossRef] [PubMed]

101. D'Souza, S.; del Prete, D.; Jin, S.; Sun, Q.; Huston, A.J.; Kostov, F.E.; Sammut, B.; Hong, C.S.; Anderson, J.L.; Patrene, K.D.; et al. Gfil expressed in bone marrow stromal cells is a novel osteoblast suppressor in patients with multiple myeloma bone disease. Blood 2011, 118, 6871-6880. [CrossRef] [PubMed]

102. Pozzi, S.; Fulciniti, M.; Yan, H.; Vallet, S.; Eda, H.; Patel, K.; Santo, L.; Cirstea, D.; Hideshima, T.; Schirtzinge, L.; et al. In vivo and in vitro effects of a novel anti-dkk1 neutralizing antibody in multiple myeloma. Bone 2013, 53,487-496. [CrossRef] [PubMed]

103. Adamik, J.; Jin, S.; Sun, Q.; Zhang, P.; Weiss, K.R.; Anderson, J.L.; Silbermann, R.; Roodman, G.D.; Galson, D.L. Ezh2 or hdac1 inhibition reverses multiple myeloma-induced epigenetic suppression of osteoblast differentiation. Mol. Cancer Res. 2017, 15, 405-417. [CrossRef] [PubMed]

104. Silbermann, R.; Roodman, G.D. Bone effects of cancer therapies: Pros and cons. Curr. Opin. Support. Palliat. Care 2011, 5, 251-257. [CrossRef] [PubMed]

105. Bianchi, G.; Munshi, N.C. Pathogenesis beyond the cancer clone(s) in multiple myeloma. Blood 2015, 125, 3049-3058. [CrossRef] [PubMed]

106. Iyer, S.P.; Beck, J.T.; Stewart, A.K.; Shah, J.; Kelly, K.R.; Isaacs, R.; Bilic, S.; Sen, S.; Munshi, N.C. A phase ib multicentre dose-determination study of bhq880 in combination with anti-myeloma therapy and zoledronic acid 
in patients with relapsed or refractory multiple myeloma and prior skeletal-related events. Br. J. Haematol. 2014, 167, 366-375. [CrossRef] [PubMed]

107. Fulciniti, M.; Tassone, P.; Hideshima, T.; Vallet, S.; Nanjappa, P.; Ettenberg, S.A.; Shen, Z.; Patel, N.; Tai, Y.-T.; Chauhan, D.; et al. Anti-dkk1 mab (bhq880) as a potential therapeutic agent for multiple myeloma. Blood 2009, 114, 371. [CrossRef] [PubMed]

108. Kocemba, K.A.; Groen, R.W.; van Andel, H.; Kersten, M.J.; Mahtouk, K.; Spaargaren, M.; Pals, S.T. Transcriptional silencing of the wnt-antagonist dkk1 by promoter methylation is associated with enhanced wnt signaling in advanced multiple myeloma. PLoS ONE 2012, 7, e30359. [CrossRef] [PubMed]

109. Huang, H.; Dou, L.; Song, J.; Luo, J. Cbfa2t2 is required for bmp-2-induced osteogenic differentiation of mesenchymal stem cells. Biochem. Biophys. Res. Commun. 2018, 496, 1095-1101. [CrossRef] [PubMed]

110. Charhon, S.A.; Chapuy, M.C.; Delvin, E.E.; Valentin-Opran, A.; Edouard, C.M.; Meunier, P.J. Histomorphometric analysis of sclerotic bone metastases from prostatic carcinoma special reference to osteomalacia. Cancer 1983, 51, 918-924. [CrossRef]

111. Clarke, N.W.; McClure, J.; George, N.J. Morphometric evidence for bone resorption and replacement in prostate cancer. Br. J. Urol. 1991, 68, 74-80. [CrossRef] [PubMed]

112. Morris, M.J.; Scher, H.I. Clinical approaches to osseous metastases in prostate cancer. Oncologist 2003, 8, 161-173. [CrossRef] [PubMed]

113. Logothetis, C.; Morris, M.J.; Den, R.; Coleman, R.E. Current perspectives on bone metastases in castrate-resistant prostate cancer. Cancer Metastasis Rev. 2018, 37, 189-196. [CrossRef] [PubMed]

114. Sekita, A.; Matsugaki, A.; Nakano, T. Disruption of collagen/apatite alignment impairs bone mechanical function in osteoblastic metastasis induced by prostate cancer. Bone 2017, 97, 83-93. [CrossRef] [PubMed]

115. Matsugaki, A.; Aramoto, G.; Ninomiya, T.; Sawada, H.; Hata, S.; Nakano, T. Abnormal arrangement of a collagen/apatite extracellular matrix orthogonal to osteoblast alignment is constructed by a nanoscale periodic surface structure. Biomaterials 2015, 37, 134-143. [CrossRef] [PubMed]

116. Wan, X.; Corn, P.G.; Yang, J.; Palanisamy, N.; Starbuck, M.W.; Efstathiou, E.; Li Ning Tapia, E.M.; Zurita, A.J.; Aparicio, A.; Ravoori, M.K.; et al. Prostate cancer cell-stromal cell crosstalk via fgfr1 mediates antitumor activity of dovitinib in bone metastases. Sci. Transl. Med. 2014, 6, 252ra122. [CrossRef] [PubMed]

117. Fizazi, K.; Yang, J.; Peleg, S.; Sikes, C.R.; Kreimann, E.L.; Daliani, D.; Olive, M.; Raymond, K.A.; Janus, T.J.; Logothetis, C.J.; et al. Prostate cancer cells-osteoblast interaction shifts expression of growth/survival-related genes in prostate cancer and reduces expression of osteoprotegerin in osteoblasts. Clin. Cancer Res. 2003, 9 , 2587-2597. [PubMed]

118. Oberneder, R.; Riesenberg, R.; Kriegmair, M.; Bitzer, U.; Klammert, R.; Schneede, P.; Hofstetter, A.; Riethmuller, G.; Pantel, K. Immunocytochemical detection and phenotypic characterization of micrometastatic tumour cells in bone marrow of patients with prostate cancer. Urol. Res. 1994, 22, 3-8. [CrossRef] [PubMed]

119. Ottewell, P.D. The role of osteoblasts in bone metastasis. J. Bone Oncol. 2016, 5, 124-127. [CrossRef] [PubMed]

120. Liao, J.; Li, X.; Koh, A.J.; Berry, J.E.; Thudi, N.; Rosol, T.J.; Pienta, K.J.; McCauley, L.K. Tumor expressed pthrp facilitates prostate cancer-induced osteoblastic lesions. Int. J. Cancer 2008, 123, 2267-2278. [CrossRef] [PubMed]

121. Clines, G.A.; Mohammad, K.S.; Bao, Y.; Stephens, O.W.; Suva, L.J.; Shaughnessy, J.D., Jr.; Fox, J.W.; Chirgwin, J.M.; Guise, T.A. Dickkopf homolog 1 mediates endothelin-1-stimulated new bone formation. Mol. Endocrinol. 2007, 21, 486-498. [CrossRef] [PubMed]

122. David Roodman, G.; Silbermann, R. Mechanisms of osteolytic and osteoblastic skeletal lesions. Bonekey Rep. 2015, 4, 753. [CrossRef] [PubMed]

123. Carducci, M.A.; Saad, F.; Abrahamsson, P.A.; Dearnaley, D.P.; Schulman, C.C.; North, S.A.; Sleep, D.J.; Isaacson, J.D.; Nelson, J.B. A phase 3 randomized controlled trial of the efficacy and safety of atrasentan in men with metastatic hormone-refractory prostate cancer. Cancer 2007, 110, 1959-1966. [CrossRef] [PubMed]

124. Carducci, M.A.; Nelson, J.B.; Bowling, M.K.; Rogers, T.; Eisenberger, M.A.; Sinibaldi, V.; Donehower, R.; Leahy, T.L.; Carr, R.A.; Isaacson, J.D.; et al. Atrasentan, an endothelin-receptor antagonist for refractory adenocarcinomas: Safety and pharmacokinetics. J. Clin. Oncol. 2002, 20, 2171-2180. [CrossRef] [PubMed]

125. Carducci, M.A.; Padley, R.J.; Breul, J.; Vogelzang, N.J.; Zonnenberg, B.A.; Dallani, D.D.; Schulman, C.C.; Nabulsi, A.A.; Humerickhouse, R.A.; Weinberg, M.A.; et al. Effect of endothelin-a receptor blockade with 
atrasentan on tumor progression in men with hormone-refractory prostate cancer; a randomized, phase ii, placebo-controlled trial. J. Clin. Oncol. 2003, 21, 679-689. [CrossRef] [PubMed]

126. Quinn, D.I.; Tangen, C.M.; Hussain, M.; Lara, P.N., Jr.; Goldkorn, A.; Moinpour, C.M.; Garzotto, M.G.; Mack, P.C.; Carducci, M.A.; Monk, J.P.; et al. Docetaxel and atrasentan versus docetaxel and placebo for men with advanced castration-resistant prostate cancer (swog s0421): A randomised phase 3 trial. Lancet Oncol. 2013, 14, 893-900. [CrossRef]

127. Suominen, M.I.; Fagerlund, K.M.; Rissanen, J.P.; Konkol, Y.M.; Morko, J.P.; Peng, Z.; Alhoniemi, E.J.; Laine, S.K.; Corey, E.; Mumberg, D.; et al. Radium-223 inhibits osseous prostate cancer growth by dual targeting of cancer cells and bone microenvironment in mouse models. Clin. Cancer Res. 2017, 23, 4335-4346. [CrossRef] [PubMed]

128. Sun, Y.-X.; Schneider, A.; Jung, Y.; Wang, J.; Dai, J.; Wang, J.; Cook, K.; Osman, N.I.; Koh-Paige, A.J.; Shim, J.; et al. Skeletal localization and neutralization of the sdf-1 (cxcl12)/cxcr4 axis blocks prostate cancer metastasis and growth in osseous sites in vivo. J. Bone Miner. Res. 2004, 20, 318-329. [CrossRef] [PubMed]

129. Karlsson, T.; Sundar, R.; Widmark, A.; Landstrom, M.; Persson, E. Osteoblast-derived factors promote metastatic potential in human prostate cancer cells, in part via non-canonical transforming growth factor beta (tgfbeta) signaling. Prostate 2018, 78, 446-456. [CrossRef] [PubMed]

130. Bussard, K.M.; Okita, N.; Sharkey, N.; Neuberger, T.; Webb, A.; Mastro, A.M. Localization of mcp-1, vegf, and il-6 in the bone microenvironment of mice bearing metastatic breast cancer. Clin. Exp. Metas 2010, 27, 331-340. [CrossRef] [PubMed]

131. Lee, C.; Whang, Y.M.; Campbell, P.; Mulcrone, P.L.; Elefteriou, F.; Cho, S.W.; Park, S.I. Dual targeting c-met and vegfr2 in osteoblasts suppresses growth and osteolysis of prostate cancer bone metastasis. Cancer Lett. 2018, 414, 205-213. [CrossRef] [PubMed]

132. Kolb, A.D.; Shupp, A.B.; Mukhopadhyay, D.; Bussard, K.M. Thomas Jefferson University, Philadelphia, PA, USA. Unpublished data, 2018.

133. Shulby, S.A.; Dolloff, N.G.; Stearns, M.E.; Meucci, O.; Fatatis, A. Cx3cr1-fractalkine expression regulates cellular mechanisms involved in adhesion, migration, and survival of human prostate cancer cells. Cancer Res. 2004, 64, 4693-4698. [CrossRef] [PubMed]

134. Jamieson-Gladney, W.L.; Zhang, Y.; Fong, A.M.; Meucci, O.; Fatatis, A. The chemokine receptor cx(3)cr1 is directly involved in the arrest of breast cancer cells to the skeleton. Breast Cancer Res. 2011, $13, \mathrm{R} 91$. [CrossRef] [PubMed]

135. Shen, F.; Zhang, Y.; Jernigan, D.L.; Feng, X.; Yan, J.; Garcia, F.U.; Meucci, O.; Salvino, J.M.; Fatatis, A. Novel small-molecule cx3cr1 antagonist impairs metastatic seeding and colonization of breast cancer cells. Mol. Cancer Res. 2016, 14, 518-527. [CrossRef] [PubMed]

136. Yumoto, K.; Eber, M.R.; Wang, J.; Cackowski, F.C.; Decker, A.M.; Lee, E.; Nobre, A.R.; Aguirre-Ghiso, J.A.; Jung, Y.; Taichman, R.S. Axl is required for tgf-beta2-induced dormancy of prostate cancer cells in the bone marrow. Sci. Rep. 2016, 6, 36520. [CrossRef] [PubMed]

137. Leconet, W.; Chentouf, M.; du Manoir, S.; Chevalier, C.; Sirvent, A.; Ait-Arsa, I.; Busson, M.; Jarlier, M.; Radosevic-Robin, N.; Theillet, C.; et al. Therapeutic activity of anti-axl antibody against triple-negative breast cancer patient-derived xenografts and metastasis. Clin. Cancer Res. 2017, 23, 2806-2816. [CrossRef] [PubMed]

138. Shiozawa, Y.; Pedersen, E.A.; Patel, L.R.; Ziegler, A.M.; Havens, A.M.; Jung, Y.; Wang, J.; Zalucha, S.; Loberg, R.D.; Pienta, K.J.; et al. Gas6/axl axis regulates prostate cancer invasion, proliferation, and survival in the bone marrow niche. Neoplasia 2010, 12, 116-127. [CrossRef] [PubMed]

139. Jung, Y.; Decker, A.M.; Wang, J.; Lee, E.; Kana, L.A.; Yumoto, K.; Cackowski, F.C.; Rhee, J.; Carmeliet, P.; Buttitta, L.; et al. Endogenous gas6 and mer receptor signaling regulate prostate cancer stem cells in bone marrow. Oncotarget 2016, 7, 25698-25711. [CrossRef] [PubMed]

140. Jin, Y.; Nie, D.; Li, J.; Du, X.; Lu, Y.; Li, Y.; Liu, C.; Zhou, J.; Pan, J. Gas6/axl signaling regulates self-renewal of chronic myelogenous leukemia stem cells by stabilizing beta-catenin. Clin. Cancer Res. 2017, 23, 2842-2855. [CrossRef] [PubMed]

141. Yu-Lee, L.Y.; Yu, G.; Lee, Y.C.; Lin, S.C.; Pan, J.; Pan, T.; Yu, K.J.; Liu, B.; Creighton, C.J.; Rodriguez-Canales, J.; et al. Osteoblast-secreted factors mediate dormancy of metastatic prostate cancer in the bone via activation of the tgfbetariii-p38mapk-ps249/t252rb pathway. Cancer Res. 2018. [CrossRef] [PubMed] 
142. Kobayashi, A.; Okuda, H.; Xing, F.; Pandey, P.R.; Watabe, M.; Hirota, S.; Pai, S.K.; Liu, W.; Fukuda, K.; Chambers, C.; et al. Bone morphogenetic protein 7 in dormancy and metastasis of prostate cancer stem-like cells in bone. J. Exp. Med. 2011, 208, 2641-2655. [CrossRef] [PubMed]

143. Lawson, M.A.; McDonald, M.M.; Kovacic, N.; Hua Khoo, W.; Terry, R.L.; Down, J.; Kaplan, W.; Paton-Hough, J.; Fellows, C.; Pettitt, J.A.; et al. Osteoclasts control reactivation of dormant myeloma cells by remodelling the endosteal niche. Nat. Commun. 2015, 6, 8983. [CrossRef] [PubMed]

144. Ghajar, C.M.; Peinado, H.; Mori, H.; Matei, I.R.; Evason, K.J.; Brazier, H.; Almeida, D.; Koller, A.; Hajjar, K.A.; Stainier, D.Y.; et al. The perivascular niche regulates breast tumour dormancy. Nat. Cell Biol. 2013, 15, 807-817. [CrossRef] [PubMed]

145. Weigelt, B.; Ghajar, C.M.; Bissell, M.J. The need for complex 3d culture models to unravel novel pathways and identify accurate biomarkers in breast cancer. Adv. Drug Deliv. Rev. 2014, 69, 42-51. [CrossRef] [PubMed]

146. Gómez-Cuadrado, L.; Tracey, N.; Ma, R.; Qian, B.; Brunton, V.G. Mouse models of metastasis: Progress and prospects. Dis. Models Mech. 2017, 10, 1061-1074. [CrossRef] [PubMed]

147. Saxena, M.; Christofori, G. Rebuilding cancer metastasis in the mouse. Mol. Oncol. 2013, 7, $283-296$. [CrossRef] [PubMed]

148. Wikman, H.; Vessella, R.; Pantel, K. Cancer micrometastasis and tumour dormancy. APMIS Acta Pathol. Microbiol. Immunol. Scand. 2008, 116, 754-770. [CrossRef] [PubMed]

149. Braun, S.; Vogl, F.D.; Naume, B.; Janni, W.; Osborne, M.P.; Coombes, R.C.; Schlimok, G.; Diel, I.J.; Gerber, B.; Gebauer, G.; et al. A pooled analysis of bone marrow micrometastasis in breast cancer. N. Engl. J. Med. 2005, 353, 793-802. [CrossRef] [PubMed]

150. Naumov, G.N.; MacDonald, I.C.; Weinmeister, P.M.; Kerkvliet, N.; Nadkarni, K.V.; Wilson, S.M.; Morris, V.L.; Groom, A.C.; Chambers, A.F. Persistence of solitary mammary carcinoma cells in a secondary site: A possible contributor to dormancy. Cancer Res. 2002, 62, 2162-2168. [PubMed]

151. Sosnoski, D.M.; Norgard, R.J.; Grove, C.D.; Foster, S.J.; Mastro, A.M. Dormancy and growth of metastatic breast cancer cells in a bone-like microenvironment. Clin. Exp. Metastasis 2015, 32, 335-344. [CrossRef] [PubMed]

152. Barkan, D.; Kleinman, H.; Simmons, J.L.; Asmussen, H.; Kamaraju, A.K.; Hoenorhoff, M.J.; Liu, Z.-Y.; Costes, S.V.; Cho, E.H.; Lockett, S.; et al. Inhibition of metastatic outgrowth from single dormant tumor cells by targeting the cytoskeleton. Cancer Res. 2008, 68, 6241-6250. [CrossRef] [PubMed]

153. Barkan, D.; El Touny, L.H.; Michalowski, A.M.; Smith, J.A.; Chu, I.; Davis, A.S.; Webster, J.D.; Hoover, S.; Simpson, R.M.; Gauldie, J.; et al. Metastatic growth from dormant cells induced by a col-I enriched fibrotic environment. Cancer Res. 2010, 70, 5706-5716. [CrossRef] [PubMed]

154. Battula, V.L.; Le, P.M.; Sun, J.C.; Nguyen, K.; Yuan, B.; Zhou, X.; Sonnylal, S.; McQueen, T.; Ruvolo, V.; Michel, K.A.; et al. Aml-induced osteogenic differentiation in mesenchymal stromal cells supports leukemia growth. JCI Insight 2017, 2. [CrossRef] [PubMed]

155. Chen, Y.; Jacamo, R.; Shi, Y.X.; Wang, R.Y.; Battula, V.L.; Konoplev, S.; Strunk, D.; Hofmann, N.A.; Reinisch, A.; Konopleva, M.; et al. Human extramedullary bone marrow in mice: A novel in vivo model of genetically controlled hematopoietic microenvironment. Blood 2012, 119, 4971-4980. [CrossRef] [PubMed]

156. Lee, J.; Li, M.; Milwid, J.; Dunham, J.; Vinegoni, C.; Gorbatov, R.; Iwamoto, Y.; Wang, F.; Shen, K.; Hatfield, K.; et al. Implantable microenvironments to attract hematopoietic stem/cancer cells. Proc. Natl Acad. Sci. USA 2012, 109, 19638-19643. [CrossRef] [PubMed]

157. Hung, B.P.; Naved, B.A.; Nyberg, E.L.; Dias, M.; Holmes, C.A.; Elisseeff, J.H.; Dorafshar, A.H.; Grayson, W.L. Three-dimensional printing of bone extracellular matrix for craniofacial regeneration. ACS Biomater. Sci. Eng. 2016, 2, 1806-1816. [CrossRef] [PubMed]

158. Lee, J.; Heckl, D.; Parekkadan, B. Multiple genetically engineered humanized microenvironments in a single mouse. Biomater. Res. 2016, 20, 19. [CrossRef] [PubMed]

159. Bersani, F.; Lee, J.; Yu, M.; Morris, R.; Desai, R.; Ramaswamy, S.; Toner, M.; Haber, D.A.; Parekkadan, B. Bioengineered implantable scaffolds as a tool to study stromal-derived factors in metastatic cancer models. Cancer Res. 2014, 74, 7229-7238. [CrossRef] [PubMed]

160. Kirschenbaum, A.; Izadmehr, S.; Yao, S.; O'Connor-Chapman, K.L.; Huang, A.; Gregoriades, E.M.; Yakar, S.; Levine, A.C. Prostatic acid phosphatase alters the rankl/opg system and induces osteoblastic prostate cancer bone metastases. Endocrinology 2016, 157, 4526-4533. [CrossRef] [PubMed] 
161. Wang, H.; Yu, C.; Gao, X.; Welte, T.; Muscarella, A.M.; Tian, L.; Zhao, H.; Zhao, Z.; Du, S.; Tao, J.; et al. The osteogenic niche promotes early-stage bone colonization of disseminated breast cancer cells. Cancer Cell 2015, 27, 193-210. [CrossRef] [PubMed]

162. Gao, H.; Chakraborty, G.; Lee-Lim, A.P.; Mo, Q.; Decker, M.; Vonica, A.; Shen, R.; Brogi, E.; Brivanlou, A.H.; Giancotti, F.G. The bmp inhibitor coco reactivates breast cancer cells at lung metastatic sites. Cell 2012, 150, 764-779. [CrossRef] [PubMed]

163. Kokabu, S.; Rosen, V. Bmp3 expression by osteoblast lineage cells is regulated by canonical wnt signaling. FEBS Open Bio 2018, 8, 168-176. [CrossRef] [PubMed]

164. Ogasawara, T.; Kawaguchi, H.; Jinno, S.; Hoshi, K.; Itaka, K.; Takato, T.; Nakamura, K.; Okayama, H. Bone morphogenetic protein 2-induced osteoblast differentiation requires smad-mediated down-regulation of cdk6. Mol. Cell. Biol. 2004, 24, 6560-6568. [CrossRef] [PubMed]

165. Chen, G.; Deng, C.; Li, Y.P. Tgf- $\beta$ and bmp signaling in osteoblast differentiation and bone formation. Int. J. Biol. Sci. 2012, 8, 272-288. [CrossRef] [PubMed]

166. Quayle, L.; Ottewell, P.D.; Holen, I. Bone metastasis: Molecular mechanisms implicated in tumour cell dormancy in breast and prostate cancer. Curr. Cancer Drug Targets 2015, 15, 469-480. [CrossRef] [PubMed]

167. Bodenstine, T.M.; Beck, B.H.; Cao, X.; Cook, L.M.; Ismail, A.; Powers, S.J.; Powers, J.K.; Mastro, A.M.; Welch, D.R. Pre-osteoblastic mc3t3-e1 cells promote breast cancer growth in bone in a murine xenograft model. Chin. J. Cancer 2011, 30, 189-196. [CrossRef] [PubMed]

168. Scimeca, M.; Antonacci, C.; Toschi, N.; Giannini, E.; Bonfiglio, R.; Buonomo, C.O.; Pistolese, C.A.; Tarantino, U.; Bonanno, E. Breast osteoblast-like cells: A reliable early marker for bone metastases from breast cancer. Clin. Breast Cancer 2017. [CrossRef] [PubMed]

169. Shiozawa, Y.; Pienta, K.J.; Taichamn, R.S. Hematopoietic stem cell niche is a potential therapeutic target for bone metastatic tumors. Clin. Cancer Res. 2011, 17, 5553-5558. [CrossRef] [PubMed]

170. Pedersen, E.A.; Shiozawa, Y.; Pienta, K.J.; Taichman, R.S. The prostate cancer bone marrow niche: More than just 'fertile soil'. Asian J. Androl. 2012, 14, 423-427. [CrossRef] [PubMed]

171. Mundy, G.R. Mechanisms of bone metastasis. Cancer 1997, 80, 1546-1556. [CrossRef]

172. Guise, T.A.; Yin, J.J.; Taylor, S.D.; Kumagai, Y.; Dallas, M.; Boyce, B.F.; Yoneda, T.; Mundy, G.R. Evidence for a causal role of parathyroid hormone-related protein in the pathogenesis of human breast-cancer-mediated osteolysis. J. Clin. Investig. 1996, 98, 1544-1549. [CrossRef] [PubMed]

173. Costa, A.G.; Cusano, N.E.; Silva, B.C.; Cremers, S.; Bilezikian, J.P. Cathepsin k: Its skeletal actions and role as a therapeutic target in osteoporosis. Nat. Rev. Rheumatol. 2011, 7, 447-456. [CrossRef] [PubMed]

174. Walia, B.; Lingenheld, E.; Duong, L.; Sanjay, A.; Drissi, H. A novel role for cathepsin k in periosteal osteoclast precursors during fracture repair. Ann. N. Y. Acad. Sci. 2018, 1415, 57-68. [CrossRef] [PubMed]

175. Kingsley, L.A.; Fournier, P.G.J.; Chirgwin, J.M.; Guise, T.A. Molecular biology of bone metastasis. Mol. Cancer Ther. 2007, 6, 2609. [CrossRef] [PubMed]

176. Bendre, M.; Montague, D.C.; Peery, T.; Akel, N.S.; Gaddy, D.; Suva, L.J. Interleukin-8 stimulation of osteoclastogenesis and bone resorption is a mechanism for the increased osteolysis of metastatic bone disease. Bone 2003, 33, 28-37. [CrossRef]

177. Bendre, M.S.; Margulies, A.G.; Walser, B.; Akel, N.S.; Bhattacharrya, S.; Skinner, R.A.; Swain, F.; Ramani, V.; Mohammad, K.S.; Wessner, L.L.; et al. Tumor-derived interleukin-8 stimulates osteolysis independent of the receptor activator of nuclear factor-kb ligand pathway. Cancer Res. 2005, 65, 11001-11009. [CrossRef] [PubMed]

178. Stewart, A.F.; Vignery, A.; Silverglate, A.; Ravin, N.D.; Livolsi, V.; Broadus, A.E.; Baron, R. Quantitative bone histomorphology in humoral hypercalcemia of malignancy: Uncoupling of bone cell activity. J. Clin. Endocrinol. Metab. 1982, 55, 219-227. [CrossRef] [PubMed]

179. Mercer, R.; Miyasaka, C.; Mastro, A.M. Metastatic breast cancer cells suppress osteoblast adhesion and differentiation. Clin. Exp. Metas 2004, 21, 427-435. [CrossRef]

180. Lee, J.W.; Chung, H.Y.; Ehrlich, L.A.; Jelinek, D.F.; Callander, N.S.; Roodman, G.D.; Choi, S.J. Il-3 expression by myeloma cells increases both osteoclast formation and growth of myeloma cells. Blood 2004, 103, 2308-2315. [CrossRef] [PubMed]

181. Mukai, T.; Otsuka, F.; Otani, H.; Yamashita, M.; Takasugi, K.; Inagaki, K.; Yamamura, M.; Makino, H. Tnf-alpha inhibits bmp-induced osteoblast differentiation through activating sapk/jnk signaling. Biochem. Biophys. Res. Commun. 2007, 356, 1004-1010. [CrossRef] [PubMed] 
182. Ballester, O.F.; Moscinski, L.C.; Lyman, G.H.; Chaney, J.V.; Saba, H.I.; Spiers, A.S.; Klein, C. High levels of interleukin- 6 are associated with low tumor burden and low growth fraction in multiple myeloma. Blood 1994, 83, 1903-1908. [PubMed]

183. Heider, U.; Zavrski, I.; Jakob, C.; Bangeroth, K.; Fleissner, C.; Langelotz, C.; Possinger, K.; Hofbauer, L.C.; Viereck, V.; Sezer, O. Expression of receptor activator of nf-kappab ligand (rankl) mrna in human multiple myeloma cells. J. Cancer Res. Clin. Oncol. 2004, 130, 469-474. [CrossRef] [PubMed]

184. Sati, H.I.; Greaves, M.; Apperley, J.F.; Russell, R.G.; Croucher, P.I. Expression of interleukin-1beta and tumour necrosis factor-alpha in plasma cells from patients with multiple myeloma. Br. J. Haematol. 1999, 104, 350-357. [CrossRef] [PubMed]

185. Choi, S.J.; Cruz, J.C.; Craig, F.; Chung, H.; Devlin, R.D.; Roodman, G.D.; Alsina, M. Macrophage inflammatory protein 1-alpha is a potential osteoclast stimulatory factor in multiple myeloma. Blood 2000, 96, 671-675. [PubMed]

186. Park, B.M.; Kim, E.J.; Nam, H.J.; Zhang, D.; Bae, C.H.; Kang, M.; Kim, H.; Lee, W.; Bogen, B.; Lim, S.K. Cyclized oligopeptide targeting lrp5/6-dkk1 interaction reduces the growth of tumor burden in a multiple myeloma mouse model. Yonsei Med. J. 2017, 58, 505-513. [CrossRef] [PubMed]

187. Dethlefsen, C.; Hojfeldt, G.; Hojman, P. The role of intratumoral and systemic il-6 in breast cancer. Breast Cancer Res. Treat. 2013, 138, 657-664. [CrossRef] [PubMed]

188. Sethi, N.; Dai, X.; Winter, C.G.; Kang, Y. Tumor-derived jagged 1 promotes osteolytic bone metastasis of breast cancer by engaging notch signaling in bone cells. Cancer Cell 2011, 19, 192-205. [CrossRef] [PubMed]

189. Ara, T.; Song, L.; Shimada, H.; Keshelava, N.; Russell, H.V.; Metelitsa, L.S.; Groshen, S.G.; Seeger, R.C.; DeClerck, Y.A. Interleukin-6 in the bone marrow microenvironment promotes the growth and survival of neuroblastoma cells. Cancer Res. 2009, 69, 329-337. [CrossRef] [PubMed]

190. Yakes, F.M.; Chen, J.; Tan, J.; Yamaguchi, K.; Shi, Y.; Yu, P.; Qian, F.; Chu, F.; Bentzien, F.; Cancilla, B.; et al. Cabozantinib (xl184), a novel met and vegfr2 inhibitor, simultaneously suppresses metastasis, angiogenesis, and tumor growth. Mol. Cancer Ther. 2011, 10, 2298-2308. [CrossRef] [PubMed]

191. Zheng, Y.; Basel, D.; Chow, S.-O.; Fong-Yee, C.; Kim, S.; Buttgereit, F.; Dunstan, C.R.; Zhou, H.; Seibel, M.J. Targeting il-6 and rankl signaling inhibits prostate cancer growth in bone. Clin. Exp. Metastasis 2014, 31, 921-933. [CrossRef] [PubMed]

192. Zhu, W.; Castro, N.J.; Cui, H.; Zhou, X.; Boualam, B.; McGrane, R.; Glazer, R.I.; Zhang, L.G. A 3d printed nano bone matrix for characterization of breast cancer cell and osteoblast interactions. Nanotechnology 2016, 27, 315103. [CrossRef] [PubMed]

193. Morinaga, Y.; Fujita, N.; Ohishi, K.; Tsuruo, T. Stimulation of interleukin-11 production from osteoblast-like cells by transforming growth factor-beta and tumor cell factors. Int. J. Cancer 1997, 71, 422-428. [CrossRef]

194. Gonzalez, A.; Garcia de Durango, C.; Alonso, V.; Bravo, B.; Rodriguez de Gortazar, A.; Wells, A.; Forteza, J.; Vidal-Vanaclocha, F. Distinct osteomimetic response of androgen-dependent and independent human prostate cancer cells to mechanical action of fluid flow: Prometastatic implications. Prostate 2017, 77, 321-333. [CrossRef] [PubMed]

195. Bendre, M.S.; Gaddy-Kurten, D.; Mon-Foote, T.; Akel, N.S.; Skinner, R.A.; Nicholas, R.W.; Suva, L.J. Expression of interleukin 8 and not parathyroid hormone-related protein by human breast cancer cells correlates with bone metastasis in vivo. Cancer Res. 2002, 62, 5571-5579. [PubMed]

196. Singh, B.; Berry, J.A.; Vincent, L.E.; Lucci, A. Involvement of il-8 in cox-2-mediated bone metastases from breast cancer. J. Surg. Res. 2006, 134, 44-51. [CrossRef] [PubMed]

197. McCoy, E.M.; Hong, H.; Pruitt, H.C.; Feng, X. Il-11 produced by breast cancer cells augments osteoclastogenesis by sustaining the pool of osteoclast progenitor cells. BMC Cancer 2013, 13, 16. [CrossRef] [PubMed]

198. Lu, Y.; Chen, Q.; Corey, E.; Xie, W.; Fan, J.; Mizokami, A.; Zhang, J. Activation of mcp-1/ccr2 axis promotes prostate cancer growth in bone. Clin. Exp. Metastasis 2009, 26, 161-169. [CrossRef] [PubMed]

199. Singh, B.; Berry, J.A.; Shoher, A.; Ayers, G.D.; Wei, C.; Lucci, A. Cox-2 involvement in breast cancer metastasis to bone. Oncogene 2007, 26, 3789. [CrossRef] [PubMed]

200. Aldridge, S.E.; Lennard, T.W.; Williams, J.R.; Birch, M.A. Vascular endothelial growth factor acts as an osteolytic factor in breast cancer metastases to bone. Br. J. Cancer 2005, 92, 1531-1537. [CrossRef] [PubMed] 
201. Yang, L.; You, S.; Kumar, V.; Zhang, C.; Cao, Y. In vitro the behaviors of metastasis with suppression of vegf in human bone metastatic lncap-derivative $\mathrm{c} 4-2 \mathrm{~b}$ prostate cancer cell line. J. Exp. Clin. Cancer Res. CR 2012, 31, 40. [CrossRef] [PubMed]

202. Chen, Y.C.; Sosnoski, D.M.; Gandhi, U.H.; Novinger, L.J.; Prabhu, K.S.; Mastro, A.M. Selenium modifies the osteoblast inflammatory stress response to bone metastatic breast cancer. Carcinogenesis 2009, 30, 1941-1948. [CrossRef] [PubMed]

203. Shiirevnyamba, A.; Takahashi, T.; Shan, H.; Ogawa, H.; Yano, S.; Kanayama, H.; Izumi, K.; Uehara, H. Enhancement of osteoclastogenic activity in osteolytic prostate cancer cells by physical contact with osteoblasts. Br. J. Cancer 2011, 104, 505-513. [CrossRef] [PubMed]

204. Xing, Y.; Wang, R.; Chen, D.; Mao, J.; Shi, R.; Wu, Z.; Kang, J.; Tian, W.; Zhang, C. Cox2 is involved in hypoxia-induced tnf-alpha expression in osteoblast. Sci. Rep. 2015, 5, 10020. [CrossRef] [PubMed]

205. Tsutsumimoto, T.; Williams, P.; Yoneda, T. The sk-n-as human neuroblastoma cell line develops osteolytic bone metastases with increased angiogenesis and cox-2 expression. J. Bone Oncol. 2014, 3, 67-76. [CrossRef] [PubMed]

206. Singh, B.; Berry, J.A.; Shoher, A.; Lucci, A. Cox-2 induces il-11 production in human breast cancer cells. J. Surg. Res. 2006, 131, 267-275. [CrossRef] [PubMed]

207. Yin, J.J.; Selander, K.; Chirgwin, J.M.; Dallas, M.; Grubbs, B.G.; Wieser, R.; Massague, J.; Mundy, G.R.; Guise, T.A. Tgf-beta signaling blockade inhibits pthrp secretion by breast cancer cells and bone metastases development. J. Clin. Investig. 1999, 103, 197-206. [CrossRef] [PubMed]

208. Korpal, M.; Yan, J.; Lu, X.; Xu, S.; Lerit, D.A.; Kang, Y. Imaging transforming growth factor-beta signaling dynamics and therapeutic response in breast cancer bone metastasis. Nat. Med. 2009, 15, 960-966. [CrossRef] [PubMed]

209. Hiraga, T.; Myoui, A.; Hashimoto, N.; Sasaki, A.; Hata, K.; Morita, Y.; Yoshikawa, H.; Rosen, C.J.; Mundy, G.R.; Yoneda, T. Bone-derived igf mediates crosstalk between bone and breast cancer cells in bony metastases. Cancer Res. 2012, 72, 4238-4249. [CrossRef] [PubMed]

210. Park, S.I.; Lee, C.; Sadler, W.D.; Koh, A.J.; Jones, J.; Seo, J.W.; Soki, F.N.; Cho, S.W.; Daignault, S.D.; McCauley, L.K. Parathyroid hormone-related protein drives a cd11b+gr1+ cell-mediated positive feedback loop to support prostate cancer growth. Cancer Res. 2013, 73, 6574-6583. [CrossRef] [PubMed]

211. Fan, Y.; Hanai, J.I.; Le, P.T.; Bi, R.; Maridas, D.; DeMambro, V.; Figueroa, C.A.; Kir, S.; Zhou, X.; Mannstadt, M.; et al. Parathyroid hormone directs bone marrow mesenchymal cell fate. Cell Metab. 2017, 25, 661-672. [CrossRef] [PubMed]

212. Cai, W.L.; Huang, W.D.; Li, B.; Chen, T.R.; Li, Z.X.; Zhao, C.L.; Li, H.Y.; Wu, Y.M.; Yan, W.J.; Xiao, J.R. Microrna-124 inhibits bone metastasis of breast cancer by repressing interleukin-11. Mol. Cancer 2018, $17,9$. [CrossRef] [PubMed]

213. Ohshiba, T.; Miyaura, C.; Ito, A. Role of prostaglandin e produced by osteoblasts in osteolysis due to bone metastasis. Biochem. Biophys. Res. Commun. 2003, 300, 957-964. [CrossRef]

214. Lee, J.H.; Kim, B.; Jin, W.J.; Kim, J.W.; Kim, H.H.; Ha, H.; Lee, Z.H. Trolox inhibits osteolytic bone metastasis of breast cancer through both pge2-dependent and independent mechanisms. Biochem. Pharmacol. 2014, 91, 51-60. [CrossRef] [PubMed]

215. Verbovsek, U.; Van Noorden, C.J.; Lah, T.T. Complexity of cancer protease biology: Cathepsin k expression and function in cancer progression. Semin. Cancer Biol. 2015, 35, 71-84. [CrossRef] [PubMed]

216. Esposito, M.; Guise, T.; Kang, Y. The biology of bone metastasis. Cold Spring Harbor Perspect. Med. 2017. [CrossRef] [PubMed]

217. Dayyani, F.; Gallick, G.E.; Logothetis, C.J.; Corn, P.G. Novel therapies for metastatic castrate-resistant prostate cancer. J. Natl. Cancer Inst. 2011, 103, 1665-1675. [CrossRef] [PubMed]

218. Gobel, A.; Browne, A.J.; Thiele, S.; Rauner, M.; Hofbauer, L.C.; Rachner, T.D. Potentiated suppression of dickkopf-1 in breast cancer by combined administration of the mevalonate pathway inhibitors zoledronic acid and statins. Breast Cancer Res. Treat. 2015, 154, 623-631. [CrossRef] [PubMed]

219. Qiang, Y.W.; Barlogie, B.; Rudikoff, S.; Shaughnessy, J.D., Jr. Dkk1-induced inhibition of wnt signaling in osteoblast differentiation is an underlying mechanism of bone loss in multiple myeloma. Bone 2008, 42, 669-680. [CrossRef] [PubMed] 
220. Yao, G.-Q.; Wu, J.-J.; Troiano, N.; Insogna, K. Targeted over-expression of dkk1 in osteoblasts reduces bone mass but does not impair the anabolic response to intermittent pth treatment in mice. J. Bone Miner. Metab. 2011, 29, 141-148. [CrossRef] [PubMed]

221. Kudo, O.; Sabokbar, A.; Pocock, A.; Itonaga, I.; Fujikawa, Y.; Athanasou, N.A. Interleukin-6 and interleukin-11 support human osteoclast formation by a rankl-independent mechanism. Bone 2003, 32, 1-7. [CrossRef]

222. Kwan Tat, S.; Padrines, M.; Theoleyre, S.; Heymann, D.; Fortun, Y. Il-6, rankl, tnf-alpha/il-1: Interrelations in bone resorption pathophysiology. Cytokine Growth Factor Rev. 2004, 15, 49-60. [PubMed]

223. Zhu, Z.; Huang, P.; Chong, Y.; George, S.K.; Wen, B.; Han, N.; Liu, Z.; Kang, L.; Lin, N. Nucleus pulposus cells derived igf- 1 and $\mathrm{mcp}-1$ enhance osteoclastogenesis and vertebrae disruption in lumbar disc herniation. Int. J. Clin. Exp. Pathol. 2014, 7, 8520-8531. [PubMed]

224. Ohba, T.; Cole, H.A.; Cates, J.M.; Slosky, D.A.; Haro, H.; Ando, T.; Schwartz, H.S.; Schoenecker, J.G. Bisphosphonates inhibit osteosarcoma-mediated osteolysis via attenuation of tumor expression of mcp-1 and rankl. J. Bone Miner. Res. 2014, 29, 1431-1445. [CrossRef] [PubMed]

225. Graves, D.T.; Jiang, Y.; Valente, A.J. The expression of monocyte chemoattractant protein-1 and other chemokines by osteoblasts. Front. Biosci. 1999, 4, D571-D580. [CrossRef] [PubMed]

226. Koide, N.; Nishio, A.; Sato, T.; Sugiyama, A.; Miyagawa, S. Significance of macrophage chemoattractant protein-1 expression and macrophage infiltration in squamous cell carcinoma of the esophagus. Am. J. Gastroenterol. 2004, 99, 1667-1674. [CrossRef] [PubMed]

227. Lu, Y.; Cai, Z.; Galson, D.L.; Xiao, G.; Liu, Y.; George, D.E.; Melhem, M.F.; Yao, Z.; Zhang, J. Monocyte chemotactic protein-1 (mcp-1) acts as a paracrine and autocrine factor for prostate cancer growth and invasion. Prostate 2006, 66, 1311-1318. [CrossRef] [PubMed]

228. Mestdagt, M.; Polette, M.; Buttice, G.; Noel, A.; Ueda, A.; Foidart, J.-M.; Gilles, C. Transactivation of mcp-1/ccl2 by $\beta$-catenin/tcf-4 in human breast cancer cells. Int. J. Cancer 2006, 118, 35-42. [CrossRef] [PubMed]

229. Neumark, E.; Sagi-Assif, O.; Shalmon, B.; Ben-Baruch, A.; Witz, I.P. Progression of mouse mammary tumors: Mcp-1-tnf-alpha cross regulatory pathway and clonal expression of promalignancy and antimalignancy factors. Int J. Cancer 2003, 106, 879-886. [CrossRef] [PubMed]

230. Mercer, R.; Mastro, A.M. Cytokines secreted by bone-metastatic breast cancer cells alter the expression pattern of f-actin and reduce focal adhesion plaques in osteoblasts through PI3K. Exp. Cell Res. 2005, 310, 270-281. [CrossRef] [PubMed]

231. Jung, Y.; Wang, J.; Schneider, A.; Sun, Y.X.; Koh-Paige, A.J.; Osman, N.I.; McCauley, L.K.; Taichman, R.S. Regulation of sdf-1 (cxcl12) production by osteoblasts; a possible mechanism for stem cell homing. Bone 2006, 38, 497-508. [CrossRef] [PubMed]

232. Sun, Y.X.; Fang, M.; Wang, J.; Cooper, C.R.; Pienta, K.J.; Taichman, R.S. Expression and activation of alpha v beta 3 integrins by sdf-1/cxc12 increases the aggressiveness of prostate cancer cells. Prostate 2007, 67, 61-73. [CrossRef] [PubMed]

233. Yu, K.J.; Li, J.K.; Lee, Y.C.; Yu, G.; Lin, S.C.; Pan, T.; Satcher, R.L.; Titus, M.A.; Yu-Lee, L.Y.; Weng, W.H.; et al. Cabozantinib-induced osteoblast secretome promotes survival and migration of metastatic prostate cancer cells in bone. Oncotarget 2017, 8, 74987-75006. [CrossRef] [PubMed]

234. Kiyama, S.; Morrison, K.; Zellweger, T.; Akbari, M.; Cox, M.; Yu, D.; Miyake, H.; Gleave, M.E. Castration-induced increases in insulin-like growth factor-binding protein 2 promotes proliferation of androgen-independent human prostate lncap tumors. Cancer Res. 2003, 63, 3575-3584. [PubMed]

235. Sun, Y.; Campisi, J.; Higano, C.; Beer, T.M.; Porter, P.; Coleman, I.; True, L.; Nelson, P.S. Treatment-induced damage to the tumor microenvironment promotes prostate cancer therapy resistance through wnt $16 \mathrm{~b}$. Nat. Med. 2012, 18, 1359-1368. [CrossRef] [PubMed]

236. van Andel, H.; Ren, Z.; Koopmans, I.; Joosten, S.P.; Kocemba, K.A.; de Lau, W.; Kersten, M.J.; de Bruin, A.M.; Guikema, J.E.; Clevers, H.; et al. Aberrantly expressed lgr4 empowers wnt signaling in multiple myeloma by hijacking osteoblast-derived r-spondins. Proc. Natl. Acad. Sci. USA 2017, 114, 376-381. [CrossRef] [PubMed]

237. Sukhdeo, K.; Mani, M.; Zhang, Y.; Dutta, J.; Yasui, H.; Rooney, M.D.; Carrasco, D.E.; Zheng, M.; He, H.; Tai, Y.T.; et al. Targeting the beta-catenin/tcf transcriptional complex in the treatment of multiple myeloma. Proc. Natl. Acad. Sci. USA 2007, 104, 7516-7521. [CrossRef] [PubMed] 
238. Derksen, P.W.; Tjin, E.; Meijer, H.P.; Klok, M.D.; MacGillavry, H.D.; van Oers, M.H.; Lokhorst, H.M.; Bloem, A.C.; Clevers, H.; Nusse, R.; et al. Illegitimate wnt signaling promotes proliferation of multiple myeloma cells. Proc. Natl. Acad. Sci. USA 2004, 101, 6122-6127. [CrossRef] [PubMed]

239. Nemani, N.; Santo, L.; Eda, H.; Cirstea, D.; Mishima, Y.; Patel, C.; O’Donnell, E.; Yee, A.; Raje, N. Role of decorin in multiple myeloma (mm) bone marrow microenvironment. J. Bone Miner. Res. 2015, 30, 465-470. [CrossRef] [PubMed]

240. Greenspan, S.L.; Harris, S.T.; Bone, H.; Miller, P.D.; Orwoll, E.S.; Watts, N.B.; Rosen, C.J. Bisphosphonates: Safety and efficacy in the treatment and prevention of osteoporosis. Am. Fam. Physician 2000, 61, 2731-2736. [PubMed]

241. Hillner, B.E.; Ingle, J.N.; Berenson, J.R.; Janjan, N.A.; Albain, K.S.; Lipton, A.; Yee, G.; Biermann, J.S.; Chlebowski, R.T.; Pfister, D.G. American society of clinical oncology guideline on the role of bisphosphonates in breast cancer. J. Clin. Oncol. 2000, 18, 1378-1391. [CrossRef] [PubMed]

242. Delmas, P.D.; Demiaux, B.; Malaval, L.; Chapuy, M.C.; Edouard, C.; Meunier, P.J. Serum bone gamma carboxyglutamic acid-containing protein in primary hyperthyroidism and in malignant hypercalcemia. J. Clin. Investig. 1986, 77, 985-991. [CrossRef] [PubMed]

243. Kukreja, S.C.; Rosol, T.J.; Shevrin, D.H.; York, P.A. Quantitative bone histomorphometry in nude mice bearing a human squamous cell lung cancer. J. Bone Min. Res. 1998, 3, 341-346. [CrossRef] [PubMed]

244. Galasko, C.S. Mechanisms of lytic and blastic metastatic disease of bone. Clin. Orthop. 1982, 169, $20-27$. [CrossRef]

245. Martin, T.J.; Moseley, J.M. Mechanisms in the skeletal complications of breast cancer. Endocr. Relat. Cancer 2000, 7, 271-284. [CrossRef] [PubMed]

246. Fioramonti, M.; Santini, D.; Iuliani, M.; Ribelli, G.; Manca, P.; Papapietro, N.; Spiezia, F.; Vincenzi, B.; Denaro, V.; Russo, A.; et al. Cabozantinib targets bone microenvironment modulating human osteoclast and osteoblast functions. Oncotarget 2017, 8, 20113-20121. [CrossRef] [PubMed]

247. Haider, M.T.; Hunter, K.D.; Robinson, S.P.; Graham, T.J.; Corey, E.; Dear, T.N.; Hughes, R.; Brown, N.J.; Holen, I. Rapid modification of the bone microenvironment following short-term treatment with cabozantinib in vivo. Bone 2015, 81, 581-592. [CrossRef] [PubMed]

248. Dai, J.; Zhang, H.; Karatsinides, A.; Keller, J.M.; Kozloff, K.M.; Aftab, D.T.; Schimmoller, F.; Keller, E.T. Cabozantinib inhibits prostate cancer growth and prevents tumor-induced bone lesions. Clin. Cancer Res. 2014, 20, 617-630. [CrossRef] [PubMed]

249. Pond, G.R.; Sonpavde, G.; Fizazi, K.; De Bono, J.S.; Basch, E.M.; Scher, H.I.; Smith, M.R. Cabozantinib for metastatic castration-resistant prostate cancer (mcrpc) following docetaxel: Combined analysis of two phase iii trials. J. Clin. Oncol. 2018, 36, 225-225. [CrossRef]

250. Smith, M.; De Bono, J.; Sternberg, C.; Le Moulec, S.; Oudard, S.; De Giorgi, U.; Krainer, M.; Bergman, A.; Hoelzer, W.; De Wit, R.; et al. Phase iii study of cabozantinib in previously treated metastatic castration-resistant prostate cancer: Comet-1. J. Clin. Oncol. 2016, 34, 3005-3013. [CrossRef] [PubMed]

251. Kimura, Y.; Matsugaki, A.; Sekita, A.; Nakano, T. Alteration of osteoblast arrangement via direct attack by cancer cells: New insights into bone metastasis. Sci. Rep. 2017, 7, 44824. [CrossRef] [PubMed]

252. Row, S.; Liu, Y.; Alimperti, S.; Agarwal, S.K.; Andreadis, S.T. Cadherin-11 is a novel regulator of extracellular matrix synthesis and tissue mechanics. J. Cell Sci. 2016, 129, 2950-2961. [CrossRef] [PubMed]

253. Langhe, R.P.; Gudzenko, T.; Bachmann, M.; Becker, S.F.; Gonnermann, C.; Winter, C.; Abbruzzese, G.; Alfandari, D.; Kratzer, M.-C.; Franz, C.M.; et al. Cadherin-11 localizes to focal adhesions and promotes cell-substrate adhesion. Nat. Commun. 2016, 7, 10909. [CrossRef] [PubMed]

254. Kjenseth, A.; Fykerud, T.A.; Sirnes, S.; Bruun, J.; Yohannes, Z.; Kolberg, M.; Omori, Y.; Rivedal, E.; Leithe, E. The gap junction channel protein connexin 43 is covalently modified and regulated by sumoylation. J. Biol. Chem. 2012, 287, 15851-15861. [CrossRef] [PubMed]

255. Ishimoto, T.; Nakano, T.; Umakoshi, Y.; Yamamoto, M.; Tabata, Y. Degree of biological apatite c-axis orientation rather than bone mineral density controls mechanical function in bone regenerated using recombinant bone morphogenetic protein-2. J. Bone Miner. Res. 2013, 28, 1170-1179. [CrossRef] [PubMed]

256. Skedros, J.G.; Dayton, M.R.; Sybrowsky, C.L.; Bloebaum, R.D.; Bachus, K.N. The influence of collagen fiber orientation and other histocompositional characteristics on the mechanical properties of equine cortical bone. J. Exp. Biol. 2006, 209, 3025. [CrossRef] [PubMed] 
257. Shiraishi, A.; Miyabe, S.; Nakano, T.; Umakoshi, Y.; Ito, M.; Mihara, M. The combination therapy with alfacalcidol and risedronate improves the mechanical property in lumbar spine by affecting the material properties in an ovariectomized rat model of osteoporosis. BMC Musculoskelet. Disord. 2009, 10, 66. [CrossRef] [PubMed]

258. Hassan, M.Q.; Maeda, Y.; Taipaleenmaki, H.; Zhang, W.; Jafferji, M.; Gordon, J.A.; Li, Z.; Croce, C.M.; van Wijnen, A.J.; Stein, J.L.; et al. Mir-218 directs a wnt signaling circuit to promote differentiation of osteoblasts and osteomimicry of metastatic cancer cells. J. Biol. Chem. 2012, 287, 42084-42092. [CrossRef] [PubMed]

259. Tan, C.C.; Li, G.X.; Tan, L.D.; Du, X.; Li, X.Q.; He, R.; Wang, Q.S.; Feng, Y.M. Breast cancer cells obtain an osteomimetic feature via epithelial-mesenchymal transition that have undergone bmp2/runx2 signaling pathway induction. Oncotarget 2016, 7, 79688-79705. [CrossRef] [PubMed]

260. Hagberg Thulin, M.; Jennbacken, K.; Damber, J.E.; Welen, K. Osteoblasts stimulate the osteogenic and metastatic progression of castration-resistant prostate cancer in a novel model for in vitro and in vivo studies. Clin. Exp. Metastasis 2014, 31, 269-283. [CrossRef] [PubMed]

261. Rucci, N.; Teti, A. Osteomimicry: How the seed grows in the soil. Calcif. Tissue Int. 2018, 102, $131-140$. [CrossRef] [PubMed]

262. Graham, T.R.; Agrawal, K.C.; Abdel-Mageed, A.B. Independent and cooperative roles of tumor necrosis factor-alpha, nuclear factor-kappab, and bone morphogenetic protein-2 in regulation of metastasis and osteomimicry of prostate cancer cells and differentiation and mineralization of mc3t3-e1 osteoblast-like cells. Cancer Sci. 2010, 101, 103-111. [PubMed]

(c) 2018 by the authors. Licensee MDPI, Basel, Switzerland. This article is an open access article distributed under the terms and conditions of the Creative Commons Attribution (CC BY) license (http://creativecommons.org/licenses/by/4.0/). 